\title{
35. ORGANIC FACIES VARIATIONS IN THE MESOZOIC SOUTH ATLANTIC ${ }^{1}$
}

\author{
Deborah Gilbert, Exxon Production Research Company, Houston, Texas
}

\begin{abstract}
Visual kerogen and total organic carbon determinations indicate that there are two periods of organic enrichment events in the Mesozoic sediments of the South Atlantic. The first period, from the Late Jurassic through the late Aptian, is recorded in sediments from the Falkland Plateau, the Cape Basin, and the Angola Basin. Apparently, salinity stratification in the restricted basin, coupled with rising sea level, led to bottom water anoxia and organic enrichment. The second event, from the late Albian to the Santonian period, is recorded in sediments from the Angola Basin and the Sao Paulo Plateau. It appears to have been caused by development of an anoxic oxygen minimum zone at midwater depths. Organic matter sedimentation in the Mesozoic South Atlantic is controlled by geologic, climatic, eustatic, and oceanographic factors.
\end{abstract}

\section{INTRODUCTION}

The purpose of this chapter is to document variations in the types of organic matter in Mesozoic sediments of the South Atlantic and to describe the controls on organic matter distribution (Fig. 1). The Mesozoic sediments recovered from the South Atlantic by the Deep Sea Drilling Project (DSDP) fall into two categories: (1) organic-rich Cretaceous and Jurassic black shales, and (2) organic-poor (TOC less than 1\%) nannofossil oozes, chalks, and clays. Samples were analyzed for total organic carbon (TOC) and, by transmitted light microscopy, for organic matter types (OMT); selected samples were pyrolyzed using a Chromalytics MP-3 instrument. The organic matter was identified using criteria established by Masran and Pocock (1981).

Most of the samples analyzed in this study were collected by the author from the DSDP core repository at Lamont Doherty Geological Observatory in New York. The samples from Site 511 on the Falkland Plateau were collected by Dr. F. M. Weaver during DSDP Leg 71 . Dr. P. A. Meyers collected the samples from Hole 530A on DSDP Leg 75. Original sample locations include the Falkland Plateau, the Angola Basin, the Cape Basin, the Sáo Paulo Plateau, the Rio Grande Rise, and the Walvis Ridge.

\section{Falkland Plateau (Sites 327, 330, 511)}

These sites, located only about $10 \mathrm{~km}$ apart, were drilled on the northern edge of the Falkland Plateau (see Tables 1-3 and Figs. 1, 2). Drilling here penetrated the oldest sediments recovered in the South Atlantic and helped to document the transition of the area from a coastal plain to an open ocean environment.

The oldest sediments, Mid-Jurassic from Site 330, are olive green limestones deposited in a fluvial coastal plain environment (Barker and Dalziel, 1977). The sediments appear to have been deposited under oxidizing

\footnotetext{
${ }^{1}$ Hay, w. W., Sibuet, J.-C., et al., Init. Repts. DSDP, 75: Washington (U.S. Govt. Printing Office).
}

conditions (Barker and Dalziel, 1977) judging from the low amount of organic carbon and the abundance of terrestrial organic material (Table 1, Fig. 2). These sediments are overlain by variously colored Late Jurassic limestones deposited in a continental shelf environment, at depths less than $400 \mathrm{~m}$, on the subsiding plateau. TOC values in these sediments vary from 0.36 to $2.01 \%$, and although the organic matter is dominantly terrestrial (woody and coaly), samples with the higher TOC values have higher amounts of amorphous kerogen (Table 1, Fig. 2).

Organic-rich sediments were deposited from Late Jurassic through Aptian times at all three sites, although the exact lithology and organic facies vary slightly between the sites. Black, massive, thinly laminated mudstones were probably deposited under reducing conditions in the basinal region of the plateau at Site 511 . These are the richest sediments sampled on the Falkland Plateau. TOC values average $3.8 \%$, and the kerogen is predominantly amorphous (Table 2, Fig. 2). The equivalent units at Sites $\mathbf{3 2 7}$ and 330 are olive gray and black carbonaceous claystones with some interbedded micritic limestones. Site 327 averages $2.88 \%$ TOC and has slightly more amorphous kerogen than does Site 330, which has an average TOC content of $1.96 \%$ (Table 3, Fig. 2). Pyrolysis results indicate that the amorphous material at all three sites is hydrogen rich and oil prone (Table 4), suggesting a marine origin for the organic material.

At all three sites, this organic interval is capped by a late Aptian-Albian sequence of variously colored nannofossil clays, chalks, and mudstones. These sediments are rich in terrestrial organic matter and low in organic carbon (Tables 1-3; Fig. 2). This may reflect a return to more oxidizing conditions associated with an Aptian-Albian regression (Fig. 3).

\section{Cape Basin (Site 361)}

A lower to upper Aptian organic-rich sequence was deposited in the Cape Basin (see Table 5 and Fig. 4). It consists of dark gray to black sapropelic shales, greenish gray to greenish black sandy mudstones, and bluish gray to greenish gray sandstones (Bolli and Ryan, 1978). 


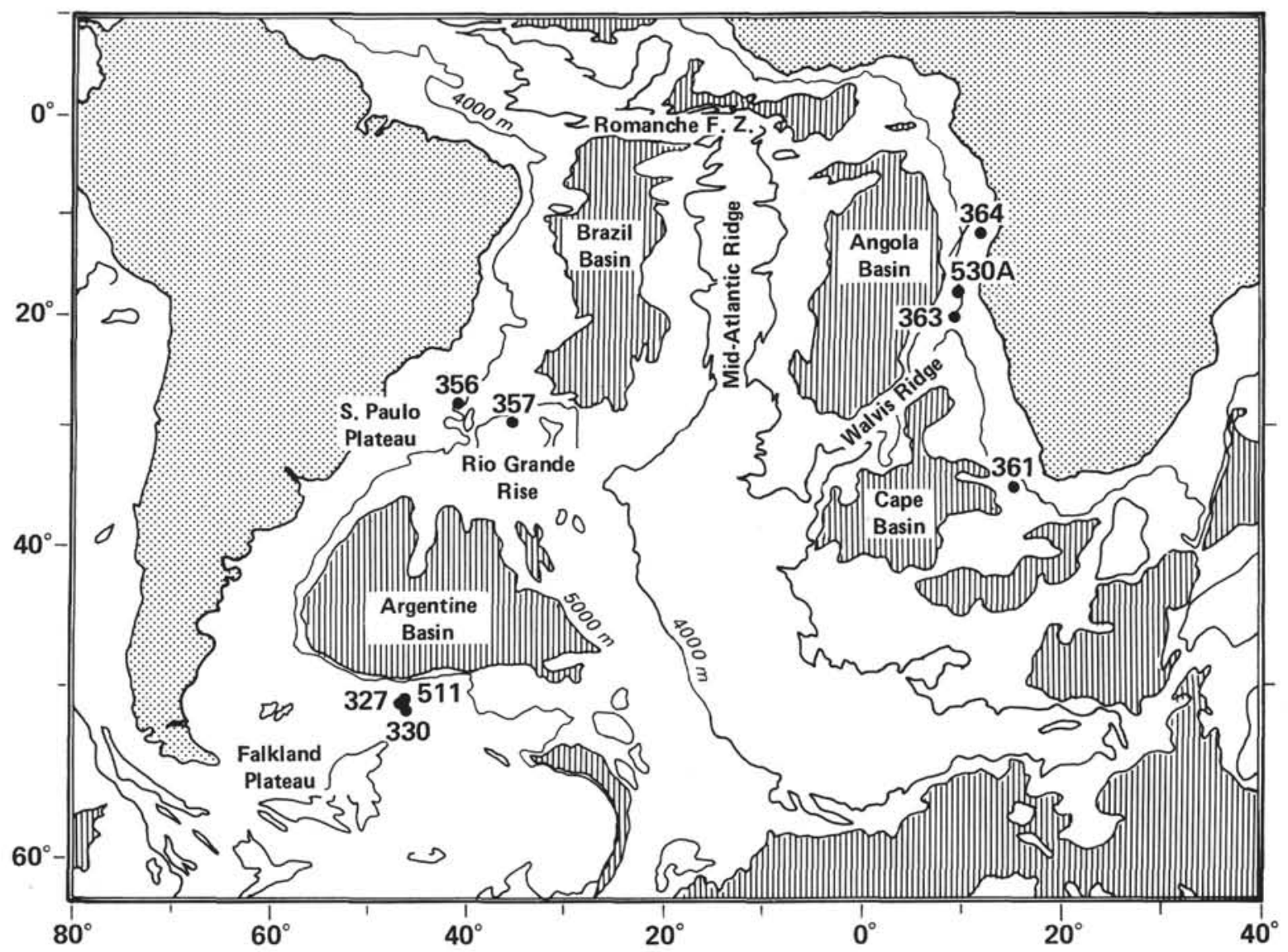

Figure 1. DSDP site locations referred to in this chapter (from Bolli, Ryan et al., 1978).

Table 1. Lithology, total organic carbon, and kerogen distribution of samples from Site 330.

\begin{tabular}{|c|c|c|c|c|c|c|c|c|c|c|c|c|}
\hline \multirow{2}{*}{$\begin{array}{l}\text { Core-Section } \\
\text { (level in } \mathrm{cm} \text { ) }\end{array}$} & \multirow[b]{2}{*}{ Age } & \multirow[b]{2}{*}{ Lithology } & \multirow{2}{*}{$\begin{array}{l}\text { Depth } \\
\text { (m) }\end{array}$} & \multirow{2}{*}{$\begin{array}{l}\text { TOC } \\
(\%)\end{array}$} & \multicolumn{8}{|c|}{ Kerogen distribution } \\
\hline & & & & & S. terr. & $P \& S$ & C & Bio. t. & AM & GA & SM & RB \\
\hline $1-1,100$ & Albian & Pinkish gray nanno clay & 130 & 0.07 & 90 & & & 10 & & & & \\
\hline $1-2,100$ & Albian & Pinkish gray nanno clay & 140 & 0.06 & 10 & & & 90 & & & & \\
\hline $2-2,60$ & Albian & Green gray nanno clay & 185 & 0.07 & 10 & 20 & & & 70 & & & \\
\hline $3-1,100$ & Aptian & Olive black sapropelic clay & 230 & 0.41 & 40 & 20 & 20 & 10 & & & 10 & \\
\hline $4-2,50$ & Neocomian & Olive gray sapropelic clay & 270 & 3.50 & 10 & & 10 & & 80 & & & \\
\hline $5-2,50$ & Oxfordian-Kimmeridgian & Olive black sapropelic claystone & 300 & 4.03 & 10 & & 10 & & 80 & & & \\
\hline $6-1,80$ & Oxfordian-Kimmeridgian & Olive black sapropelic claystone & 310 & 3.51 & 10 & 5 & 10 & & 75 & & & \\
\hline $6-6,80$ & Oxfordian-Kimmeridgian & Olive black sapropelic claystone & 320 & 3.84 & 10 & 5 & 10 & & 75 & & & \\
\hline $7-1,80$ & Oxfordian-Kimmeridgian & Olive black sapropelic claystone & 322 & 4.11 & 10 & & 10 & & 80 & & & \\
\hline $7-6,100$ & Oxfordian-Kimmeridgian & Olvie black sapropelic claystone & 330 & 3.46 & 20 & 5 & 10 & & 65 & & & \\
\hline $8-1,130$ & Oxfordian-Kimmeridgian & Olive black sapropelic claystone & 340 & 0.75 & 20 & 10 & 20 & & 50 & & & \\
\hline $8-4,100$ & Late Jurassic & Olive black sapropelic claystone & 350 & 3.22 & 10 & & 10 & & 80 & & & \\
\hline $10-2,100$ & Late Jurassic & Olive black sapropelic claystone & 410 & 1.95 & 20 & 20 & 10 & 10 & 30 & & 10 & \\
\hline $11-1,60$ & Late Jurassic & Yellow brown sparry limestone & 430 & 1.89 & 30 & 10 & 20 & 10 & 30 & & & \\
\hline $11-6,40$ & Late Jurassic & Yellow brown sparry limestone & 440 & 2.01 & 20 & 10 & 10 & 20 & 40 & & & \\
\hline $12-1,130$ & Late Jurassic & Olive gray limestone & 460 & 1.50 & 30 & 10 & 10 & 10 & 30 & & 10 & \\
\hline $12 \mathrm{CC}$ & Late Jurassic & Olive gray limestone & 465 & 0.36 & 50 & 10 & 10 & 20 & & & 10 & \\
\hline $13-1,100$ & Late Jurassic & Olive black sandy limestone & 490 & 1.03 & 30 & 10 & 20 & 20 & 10 & & 10 & \\
\hline $13-4,100$ & Late Jurassic & Olive black sandy limestone & 500 & 0.63 & 60 & 10 & 10 & 20 & & & & \\
\hline $14-1,100$ & Late Jurassic & Olive gray limestone & 510 & 0.44 & 60 & 10 & 10 & 20 & & & & \\
\hline $14-4,10$ & Late Jurassic & Olive gray limestone & 525 & 1.37 & 60 & 10 & 10 & 20 & & & & \\
\hline $15-2,63$ & Mid Jurassic & Olive gray siltstone & 550 & 0.21 & 50 & 10 & 20 & 20 & & & & \\
\hline
\end{tabular}

Note: $\mathrm{S}$. terr, = structured terrestrial; $\mathrm{P} \& \mathrm{~S}=$ pollen \& spores; $\mathrm{C}=$ coaly; Bio. $\mathrm{t}$. = biodegraded terrestrial; $\mathrm{AM}=$ amorphous; $\mathrm{GA}=$ gray amorphous; $\mathrm{SM}$ $=$ structured marine; $\mathrm{RB}=$ round bodies; $\mathrm{IF}=$ indeterminate fines. Blank space $=$ none present.

TOC values within this unit vary considerably from $0.40 \%$ to $21.70 \%$. Organic matter types fluctuate considerably, too-from $90 \%$ terrestrial to $90 \%$ amorphous (probably marine derived). There is a general correlation of high TOC with amorphous-rich samples, and low TOC with terrestrial-rich samples.
The overlying upper Aptian to Maestrichtian unit consists of alternating grayish or greenish black mudstones and reddish mudstones/claystones. There are also relatively thin parallel and cross bedded sands. With the exception of one dark gray to black shale with a TOC of $2.03 \%$, organic carbon contents are less than 
Table 2. Lithology, total organic carbon, and kerogen distribution of samples from Site 511.

\begin{tabular}{|c|c|c|c|c|c|c|c|c|c|c|c|c|}
\hline \multirow{2}{*}{$\begin{array}{l}\text { Core-Section } \\
\text { (interval in } \mathrm{cm} \text { ) }\end{array}$} & \multirow[b]{2}{*}{$\mathrm{Age}^{\mathrm{a}}$} & \multirow[b]{2}{*}{ Lithology } & \multirow{2}{*}{$\begin{array}{l}\text { Depth } \\
\text { (m) }\end{array}$} & \multirow{2}{*}{$\begin{array}{l}\text { TOC } \\
(\%)\end{array}$} & \multicolumn{8}{|c|}{ Kerogen distribution } \\
\hline & & & & & S. terr. & $P \& S$ & C & Bio. t. & AM & GA & SM & $\mathbf{R B}$ \\
\hline $57-1,7-9$ & Aptian-Late Jurassic & Mudstone & 499 & 0.36 & 20 & 30 & 15 & & & 30 & 5 & \\
\hline $57-3,7-9$ & Aptian-Late Jurassic & Mudstone & 502 & 1.44 & 30 & 40 & 20 & & 5 & & 5 & \\
\hline $57-5,26-28$ & Aptian-Late Jurassic & Mudstone & 505 & 0.49 & 20 & 25 & 20 & & 10 & 15 & 10 & \\
\hline $58-1,35-37$ & Aptian-Late Jurassic & Mudstone & 509 & 0.42 & 35 & 30 & 20 & & & 5 & 10 & \\
\hline $58-4,85-87$ & Aptian-Late Jurassic & Mudstone & 514 & 0.20 & 30 & & 10 & 10 & 40 & & 10 & \\
\hline $59-1,43-45$ & Aptian-Late Jurassic & Mudstone & 518 & 5.02 & 10 & & 5 & & 85 & & & \\
\hline $59-1,84-86$ & Aptian-Late Jurassic & Mudstone & 518.5 & 3.58 & 5 & 5 & 10 & & 80 & & & \\
\hline $59-4,22-24$ & Aptian-Late Jurassic & Mudstone & 524 & 2.37 & 10 & & 10 & & 80 & & & \\
\hline $60-1,148-150$ & Aptian-Late Jurassic & Muddy chalk and chalk & 529 & 2.61 & 10 & & 5 & & 85 & & & \\
\hline $60-3,148-150$ & Aptian-Late Jurassic & Muddy chalk and chalk & 530.5 & 3.87 & 10 & & 5 & & 85 & & & \\
\hline $60-5,120-122$ & Aptian-Late Jurassic & Muddy chalk and chalk & 534 & 3.70 & 10 & 5 & 5 & & 80 & & & \\
\hline $61-1,51-53$ & Aptian-Late Jurassic & Claystone & 537.5 & 4.98 & 10 & 5 & 5 & & 80 & & & \\
\hline $61-4,40-42$ & Aptian-Late Jurassic & Claystone & 540.5 & 5.82 & 10 & 5 & 5 & & 75 & & & 5 \\
\hline $61-5,40-42$ & Aptian-Late Jurassic & Claystone & 542 & 4.78 & 5 & & 5 & & 90 & & & \\
\hline $62-1,28-30$ & Aptian-Late Jurassic & Claystone and nannofossil & 547 & 4.60 & 5 & & & & 90 & & & 5 \\
\hline $62-3,25-27$ & Aptian-Late Jurassic & Claystone and nannofossil & 550 & 4.61 & 10 & & 10 & & 75 & & & 5 \\
\hline $62-5,30-32$ & Aptian-Late Jurassic & Claystone and nannofossil & 553 & 4.50 & 10 & & 5 & & 80 & & 5 & \\
\hline $63-1,120-122$ & Aptian-Late Jurassic & Claystone & 557 & 3.82 & 10 & & 5 & & 80 & & 5 & \\
\hline $63-3,35-37$ & Aptian-Late Jurassic & Claystone & 560 & 4.62 & 10 & & 10 & & 75 & & 5 & \\
\hline $63-4,3-5$ & Aptian-Late Jurassic & Claystone & 561.5 & 4.00 & 10 & & 10 & & 75 & & 5 & \\
\hline $64-1,14-16$ & Aptian-Late Jurassic & Claystone & 566 & 4.66 & 20 & & 10 & & 70 & & & \\
\hline $64-3,14-16$ & Aptian-Late Jurassic & Claystone & 569 & 3.67 & 20 & & 10 & & 65 & & 5 & \\
\hline $64-5,14-16$ & Aptian-Late Jurassic & Claystone & 572.5 & 3.21 & 10 & 5 & 20 & & 55 & & 10 & \\
\hline $65-1,46-48$ & Aptian-Late Jurassic & Claystone & 575.5 & 3.68 & 10 & 5 & 15 & & 60 & & 10 & \\
\hline $65-3,57-59$ & Aptian-Late Jurassic & Claystone & 579 & 5.52 & 5 & & 10 & & 75 & & 10 & \\
\hline $65-5,10-12$ & Aptian-Late Jurassic & Claystone & 581.5 & 5.36 & 5 & & 10 & & 85 & & & \\
\hline $66-1,20-22$ & Aptian-Late Jurassic & Nannofossil claystone & 585 & 4.38 & 5 & & 10 & & 75 & & 10 & \\
\hline $66-3,30-32$ & Aptian-Late Jurassic & Nannofossil claystone & 588.5 & 4.60 & 10 & 5 & 20 & & 45 & & 20 & \\
\hline $66-5,20-22$ & Aptian-Late Jurassic & Nannofossil claystone & 591 & 5.02 & 5 & & 10 & & 80 & & 5 & \\
\hline $67-1,80-82$ & Aptian-Late Jurassic & Nannofossil claystone & 595 & 4.82 & 10 & & 15 & & 60 & & 15 & \\
\hline $67-3,32-34$ & Aptian-Late Jurassic & Nannofossil claystone & 598.5 & 5.10 & 10 & 5 & 20 & & 60 & & 5 & \\
\hline $67-5,32-35$ & Aptian-Late Jurassic & Nannofossil claystone & 602 & 4.06 & 10 & 5 & 15 & & 60 & & 10 & \\
\hline $68-1,15-17$ & Aptian-Late Jurassic & Claystone & 604 & 4.07 & 5 & & 15 & & 75 & & 5 & \\
\hline $69-1,40-42$ & Aptian-Late Jurassic & Mudstone & 613.5 & 2.64 & 20 & 5 & 10 & & 55 & & 10 & \\
\hline $69-3,40-42$ & Aptian-Late Jurassic & Mudstone & 617.5 & 2.54 & 30 & 5 & 10 & & 45 & & 10 & \\
\hline $69-5,44-46$ & Aptian-Late Jurassic & Mudstone & 620 & 4.34 & 20 & 5 & 10 & & 45 & & 20 & \\
\hline $70-1,20-22$ & Aptian-Late Jurassic & Mudstone & 623 & 5.76 & 10 & 5 & 10 & & 65 & & 10 & \\
\hline $70-3,20-22$ & Aptian-Late Jurassic & Mudstone & 626.5 & 5.34 & 15 & & 10 & & 65 & & 10 & \\
\hline $70-5,20-22$ & Aptian-Late Jurassic & Mudstone & 630 & 3.78 & 10 & 5 & 20 & & 60 & & 5 & \\
\hline
\end{tabular}

Note: $\mathrm{S}$. terr. = structured terrestrial; $\mathrm{P} \& \mathrm{~S}=$ pollen \& spores; $\mathrm{C}=$ coaly; Bio. $\mathrm{t}$. = biodegraded terrestrial; $\mathrm{AM}=$ amorphous; $\mathrm{GA}=\mathrm{gray}$ amor phous; $\mathrm{SM}=$ structured marine; $\mathbf{R B}=$ round bodies. Blank space $=$ none present.

${ }^{\text {a }}$ Revisions of stratigraphic ages are given in Steinmetz et al., this volume.

Table 3. Lithology, total organic carbon, and kerogen distribution of samples from Site 327.

\begin{tabular}{|c|c|c|c|c|c|c|c|c|c|c|c|c|}
\hline \multirow{2}{*}{$\begin{array}{l}\text { Core-Section } \\
\text { (level in } \mathrm{cm} \text { ) }\end{array}$} & \multirow[b]{2}{*}{ Age } & \multirow[b]{2}{*}{ Lithology } & \multirow{2}{*}{$\begin{array}{l}\text { Depth } \\
\text { (m) }\end{array}$} & \multirow{2}{*}{$\begin{array}{l}\text { TOC } \\
(\%)\end{array}$} & \multicolumn{8}{|c|}{ Kerogen distribution } \\
\hline & & & & & S. terr. & P \& S & $\mathrm{C}$ & Bio. $t$. & AM & GA & $\mathrm{SM}$ & RB \\
\hline $10-1,102$ & Maestrichtian & Pale blue green foram-nanno chalk & 91 & 0.21 & 5 & & 10 & 5 & 70 & 10 & & \\
\hline $11-1,100$ & Maestrichtian & Green gray foram nano ooze & 100 & 0.12 & 25 & 10 & & 15 & 40 & & 10 & \\
\hline $13-2,50$ & Campanian & Green gray nanno ooze & 110 & 0.21 & 5 & & 5 & & 85 & 5 & & \\
\hline $14-2,100$ & Santonian & Green gray zeolitic clay & 130 & 0.06 & 20 & & 10 & 30 & 40 & & & \\
\hline $14-6,60$ & Cenomanian & Green gray micrite ooze & 140 & 0.16 & & & 5 & & 95 & & & \\
\hline $15-1,100$ & Albian & Green gray nanno clay & 150 & 0.04 & 5 & & 30 & & 60 & 5 & & \\
\hline $16-1,100$ & Albian & Olive gray nanno chalk & 180 & 0.11 & & & 20 & & 80 & & & \\
\hline $18-1,100$ & Albian & Olive gray nanno chalk & 230 & 0.04 & 5 & & 20 & & 70 & 5 & & \\
\hline $19-1,100$ & Albian & Yellow gray nanno ooze & 255 & 0.05 & & & 15 & & 80 & 5 & & \\
\hline $21-2,100$ & Albian & Olive gray nanno claystone & 310 & 0.08 & & & & 30 & 70 & & & \\
\hline $22-1,100$ & Aptian & Brown-black sapropelic claystone & 330 & 0.50 & 20 & 10 & 30 & & 35 & & 5 & \\
\hline $22-3,130$ & Aptian & Brown-black sapropelic claystone & 340 & 0.51 & 10 & 5 & 10 & & 65 & 10 & & \\
\hline $24-1,50$ & Aptian & Brown-black sapropelic claystone & 400 & 2.39 & 5 & & 5 & & 90 & & & \\
\hline $25-2,100$ & Aptian & Olive gray micritic claystone & 430 & 4.16 & 5 & & 5 & & 90 & & & \\
\hline $26-1,100$ & Neocomian & Olive gray claystone & 450 & 3.03 & 5 & & & & 95 & & & \\
\hline $27-1,85$ & Neocomian & Olive gray claystone & 460 & 1.21 & 5 & 10 & & & 85 & & & \\
\hline
\end{tabular}

Note: $\mathrm{S}$. terr. = structured terrestrial; $\mathrm{P} \& \mathrm{~S}=$ pollen \& spores; $\mathrm{C}=$ coaly; Bio. $\mathrm{t}$, = biodegraded terrestrial; $\mathrm{AM}=$ amorphous; $\mathrm{GA}=$ gray amor phous; $\mathrm{SM}=$ structured marine; $\mathrm{RB}=$ round bodies. Blank space $=$ none present.

$1 \%$. Organic matter types fluctuate between dominantly terrestrial and amorphous, with no relationship between TOC and organic matter type.

\section{Angola Basin (Site 364, Hole 530A)}

Two distinct black shale intervals were penetrated in the Angola Basin (see Tables 6, 7; Fig. 5). At Site 364, one of the intervals is upper Aptian through lower Albian, the other is late Albian through Santonian. Hole
530A cored an equivalent upper Albian-Coniacian interval.

The late Aptian through lower Albian interval is a marly dolomitic limestone with finely laminated sapropelic shales. The sapropelic layers contain on average $10 \%$ TOC and are dominated by amorphous kerogen. Rock-Eval pyrolysis data indicate that the amorphous matter in this layer was derived from planktonic organisms (type II) (Tissot et al., 1980). Our pyrolysis 

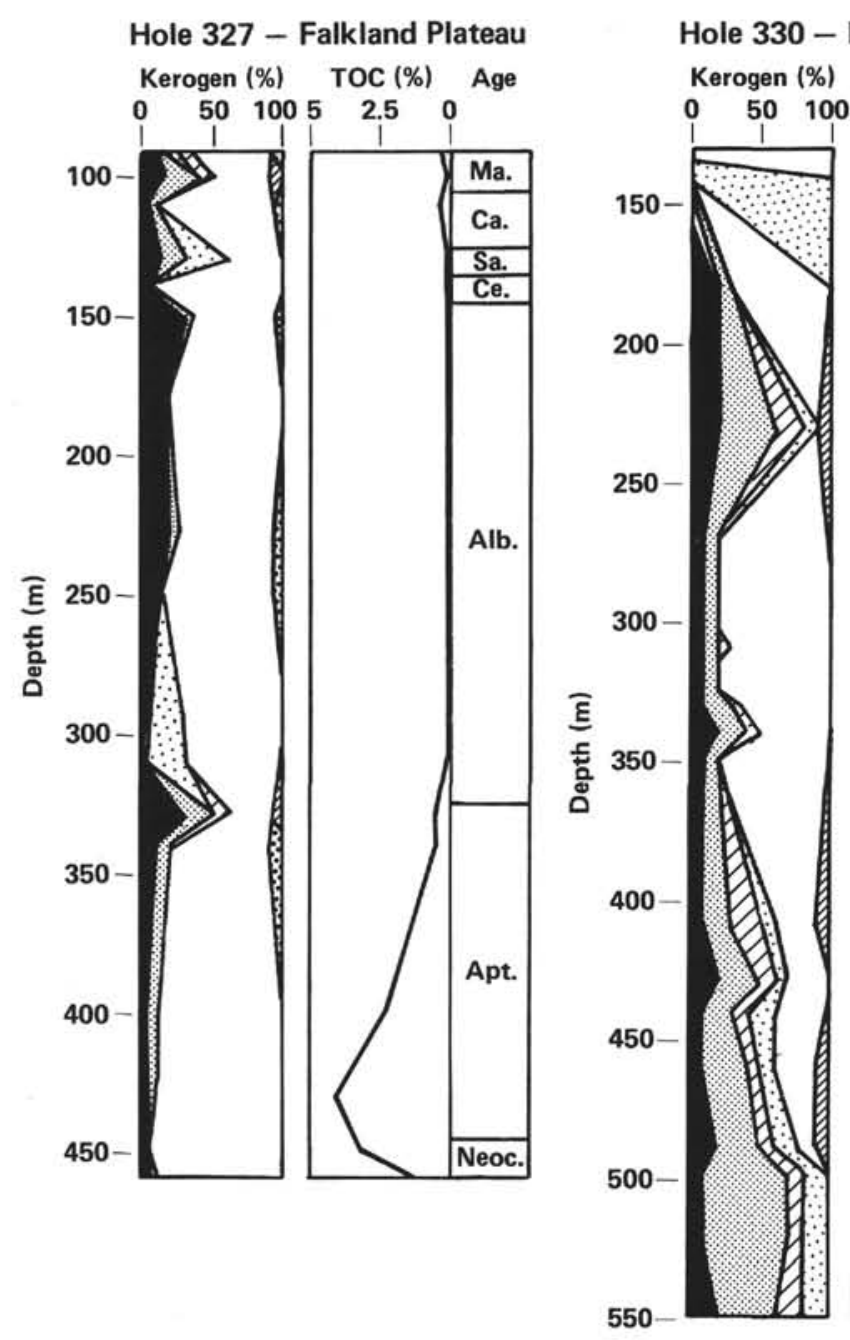
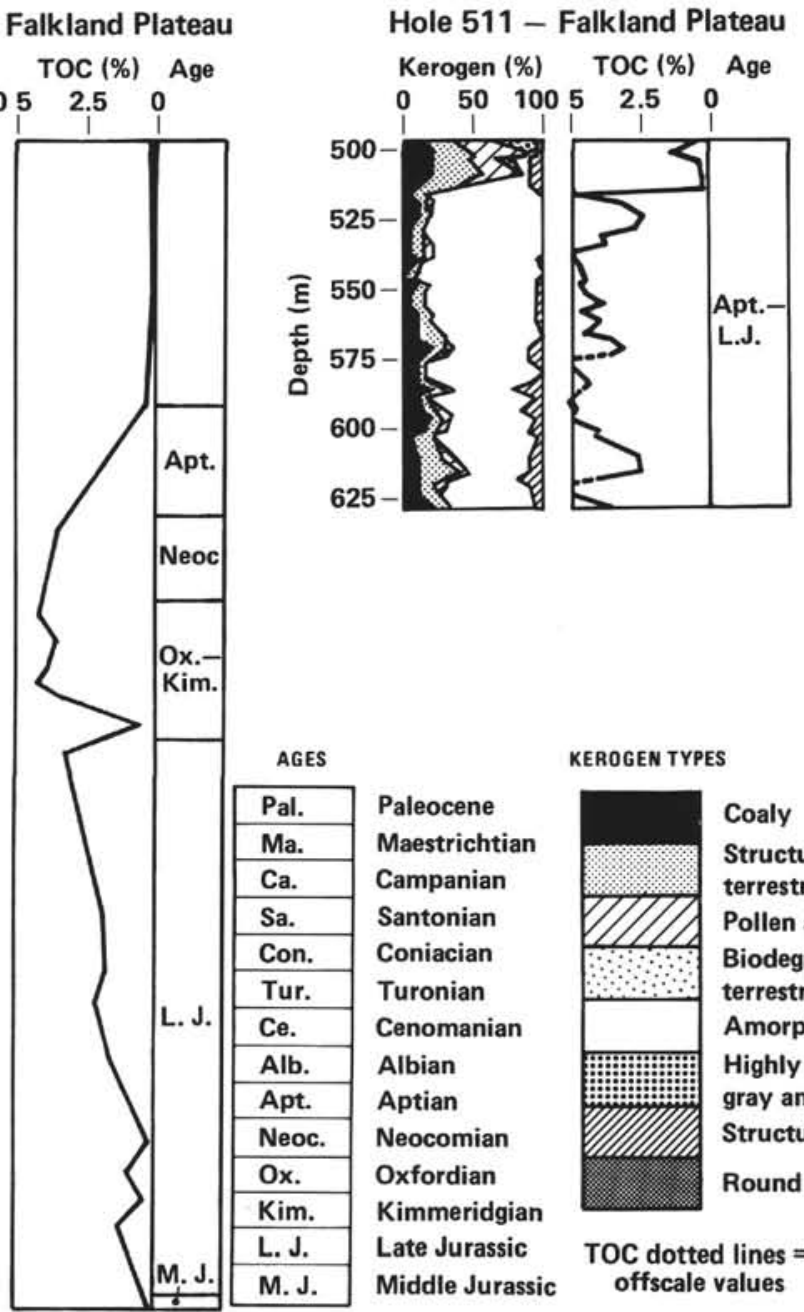

Figure 2. Kerogen, TOC, and ages of sites on the Falkland Plateau.

Table 4. Chromalytics MP-3 pyrolysis data from selected South Atlantic sites.

\begin{tabular}{|c|c|c|c|c|c|c|}
\hline Core-Section & TOC & $\begin{array}{l}\text { Rock-gas } \\
\text { index }\end{array}$ & $\begin{array}{l}\text { Rock- } \\
\text { hydrogen } \\
\text { index }\end{array}$ & $\begin{array}{c}\text { Organic } \\
\text { carbon } \\
\text { gas-index }\end{array}$ & $\begin{array}{l}\text { Organic } \\
\text { hydrogen- } \\
\text { index }\end{array}$ & $\begin{array}{c}\text { Free } \\
\text { hydrogen } \\
\text { index }\end{array}$ \\
\hline \multicolumn{7}{|l|}{ Site 327} \\
\hline $\begin{array}{l}22-1 \\
26-1\end{array}$ & $\begin{array}{l}0.48 \\
3.58\end{array}$ & $\begin{array}{l}14.9 \\
39.0\end{array}$ & $\begin{array}{r}4.7 \\
321.0\end{array}$ & $\begin{array}{l}31.0 \\
10.9\end{array}$ & $\begin{array}{r}9.8 \\
89.7\end{array}$ & $\begin{array}{l}0.7 \\
2.7\end{array}$ \\
\hline \multicolumn{7}{|l|}{ Site 330} \\
\hline $\begin{array}{l}5-2 \\
8-4\end{array}$ & $\begin{array}{l}4.43 \\
3.22\end{array}$ & $\begin{array}{l}35.7 \\
33.7\end{array}$ & $\begin{array}{l}334.9 \\
197.3\end{array}$ & $\begin{array}{r}8.0 \\
10.5\end{array}$ & $\begin{array}{l}75.6 \\
61.3\end{array}$ & $\begin{array}{l}3.6 \\
2.0\end{array}$ \\
\hline \multicolumn{7}{|l|}{ Site 511} \\
\hline $\begin{array}{l}59-1 \\
61-1 \\
63-1 \\
64-1 \\
65-1 \\
67-1\end{array}$ & $\begin{array}{l}5.02 \\
4.60 \\
3.82 \\
4.66 \\
3.68 \\
4.82\end{array}$ & $\begin{array}{l}37.4 \\
34.8 \\
39.6 \\
39.7 \\
38.6 \\
47.2\end{array}$ & $\begin{array}{l}498.5 \\
322.6 \\
332.1 \\
345.3 \\
279.3 \\
434.1\end{array}$ & $\begin{array}{r}7.5 \\
7.6 \\
10.4 \\
8.5 \\
10.5 \\
9.8\end{array}$ & $\begin{array}{l}99.3 \\
70.1 \\
86.9 \\
74.1 \\
75.9 \\
90.1\end{array}$ & $\begin{array}{r}10.7 \\
14.3 \\
10.2 \\
10.2 \\
8.4 \\
11.7\end{array}$ \\
\hline \multicolumn{7}{|l|}{ Site 361} \\
\hline $\begin{array}{l}23-2 \\
29-1\end{array}$ & $\begin{array}{l}2.00 \\
3.42\end{array}$ & $\begin{array}{l}37.9 \\
26.5\end{array}$ & $\begin{array}{l}22.6 \\
30.1\end{array}$ & $\begin{array}{r}19.0 \\
7.7\end{array}$ & $\begin{array}{r}11.3 \\
8.8\end{array}$ & $\begin{array}{l}1.1 \\
1.2\end{array}$ \\
\hline
\end{tabular}

results confirm that this is hydrogen-rich, oil-prone organic matter (Table 4).

The overlying Albian limestones and shales have considerably less organic carbon, generally less than $0.5 \%$. Although a few samples are terrestrial rich, visual kerogen analysis indicates that much of this material is amorphous. Pyrolysis data indicate that despite its appearance, this material is terrigenous (Tissot et al., 1980).

The second organic-rich interval in the Angola Basin is late Albian through Santonian at Site 364, and late Albian through Coniacian at Site 530. At Site 364, the interval is composed of two subunits: (1) greenish gray to brown nannofossil chalks interbedded with thin sapropels, and (2) greenish gray and dark greenish gray marly chalks and calcareous mudstones interlayered with black sapropelic shale. The second subunit contains barite, pyrite, and marcasite (Bolli, Ryan et al., 1978). TOC values for several of the black shales ranged from $2.89-23.4 \%$, and the kerogen was dominantly amorphous. The greenish gray marls and nannofossil chalks contained negligible amounts of organic matter; 


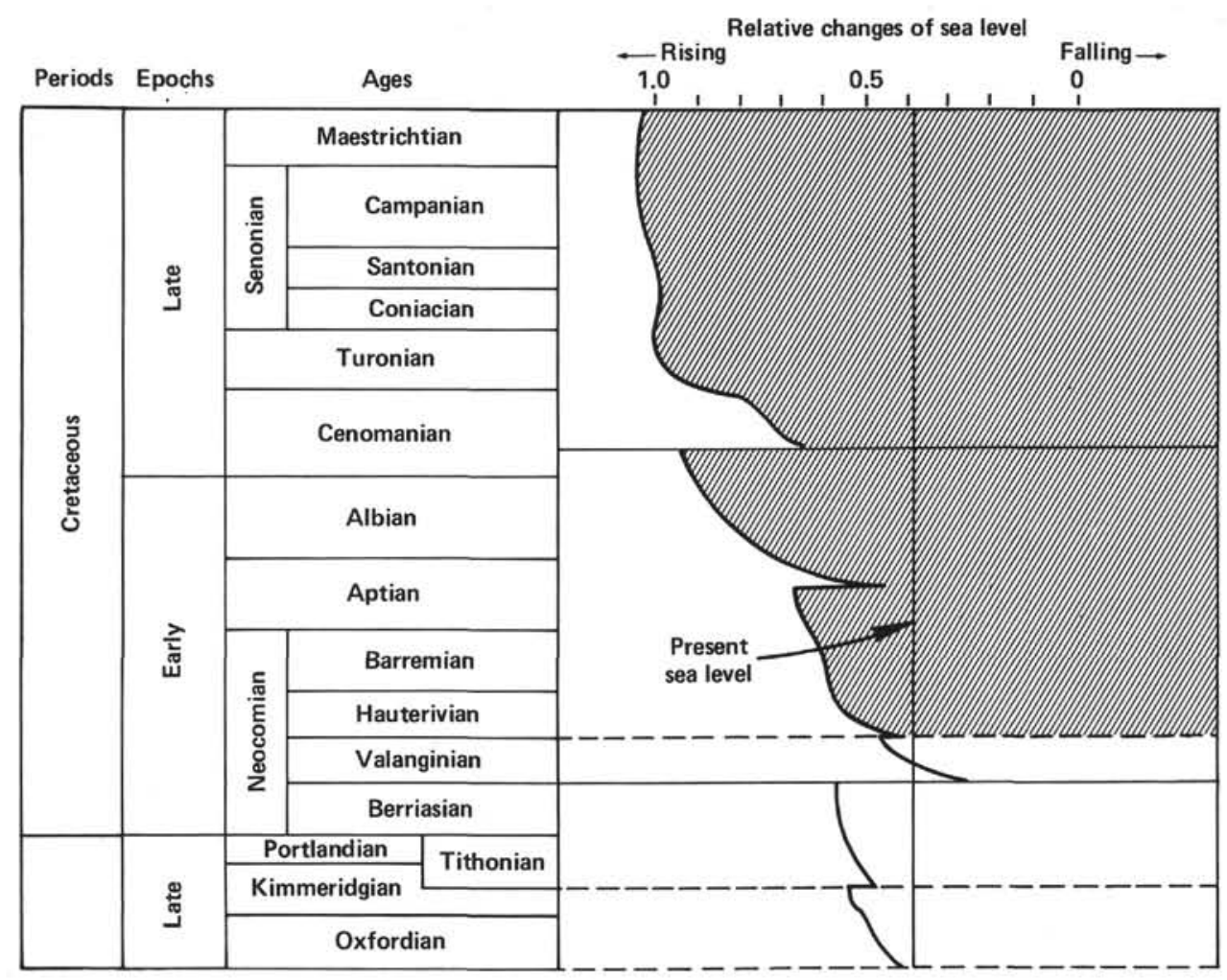

Figure 3. Sea level changes (Vail et al., 1977); Late Jurassic through Cretaceous global cycles of sea level change (Vail, 1977).

however, the one mudstone had a TOC of $1.36 \%$ and was enriched in amorphous material.

The organic facies of the green and black sediments was studied in further detail at Hole 530A. Thirty-eight samples from the late Albian to Coniacian were analyzed for TOC and organic matter types. TOC contents differed considerably between the green sediments (av. $=0.42 \%)$ and the black shales (av. $=5.06 \%$ ) (Meyers, this volume). Also, the black shales are dominated by amorphous kerogen, whereas the green sediments are amorphous rich in those sediments with greater than $0.4 \%$ TOC and terrestrial rich in those with less than $0.4 \%$ TOC.

\section{Walvis Ridge (Site 363)}

Aptian through Maestrichtian chalks, marly chalks, calcareous mudstones, and limestones were deposited at Site 363 (see Table 8 and Fig. 6). Though the sediments contain negligible amounts of organic carbon (less than $0.2 \%$ ) the kerogen type does reflect the sedimentary history of the area. The oldest sediments recovered are Aptain limestones deposited in shallow waters less than 500 $\mathrm{m}$ deep (Bolli, Ryan et al., 1978). Fragments of calcareous algae were recovered from the section and structured marine material was preserved in the kerogen fri ction.

DSDP Leg 40 staff (Bolli, Ryan et al., 1978) felt that the Campanian through Aptian interval represented a major influx of terrigenous sediments that has been extensively reworked. TOC's are low and the sediments contain poorly preserved structured terrestrial and coaly organic matter.

\section{São Paulo Plateau (Site 356)}

Late Albian through Maestrichtian and nannofossil chalks, marly calcareous chalks, and marly dolomitic and calcareous mudstones were deposited at Site 356 on the São Paulo Plateau (Supko, Perch-Nielsen, et al., 1977) (Table 9 and Fig. 7). Two distinct organic matter assemblages occur in the section. An amorphous-rich interval is present from the top of the section through the uppermost Santonian. With the exception of two Albian TOC and amorphous-rich samples, the Santonian through the Albian is dominated by low TOC's and terrestrial material.

\section{Rio Grande Rise (Site 357)}

Samples from two sedimentary units were analyzed from the Rio Grande Rise (see Table 10 and Fig. 7). The Campanian through Paleocene unit consists of predominantly pinkish gray chalks and limestones (Supko, PerchNielsen et al., 1977). This section contains mainly amorphous kerogen although the amount of organic matter is low. The Campanian-Santonian chalks and silicified limestones are also low in organic carbon but are dominated by terrestrial organic matter.

\section{DISCUSSION}

The history of the South Atlantic is the result of many interrelated variables, including the geologic framework, climate, sea level fluctuations, and oxygen contents in the water column. 
Table 5. Lithology, total organic carbon, and kerogen distribution of samples from Site 361.

\begin{tabular}{|c|c|c|c|c|c|c|c|c|c|c|c|c|}
\hline \multirow{2}{*}{$\begin{array}{l}\text { Core-Section } \\
\text { (level in } \mathrm{cm} \text { ) }\end{array}$} & \multirow[b]{2}{*}{ Age } & \multirow[b]{2}{*}{ Lithology } & \multirow{2}{*}{$\begin{array}{c}\text { Depth } \\
\text { (m) }\end{array}$} & \multirow{2}{*}{$\begin{array}{l}\text { TOC } \\
(\%)\end{array}$} & \multicolumn{8}{|c|}{ Kerogen distribution } \\
\hline & & & & & S. terr. & $P \& S$ & $\mathrm{C}$ & Bio. t. & $\mathrm{AM}$ & GA & SM & RB \\
\hline $12-1,100$ & Paleocene & Brown pelagic clay & 300 & 0.05 & & 10 & & & 90 & & & \\
\hline 13-1, Top & Paleocene & Grayish blue-green sandy mudstone & 327 & 0.10 & 50 & 10 & 20 & 10 & 10 & & & \\
\hline 14-1, Top & Maestrichtian-u. Aptian & Grayish blue-green sandy mudstone & 365 & 0.04 & 30 & 10 & 20 & 10 & 30 & & & \\
\hline 15-1, Top & Maestrichtian-u. Aptian & Blue gray shale & 403 & 0.13 & 30 & 20 & 30 & 10 & & & & \\
\hline 16-1, Top & Maestrichtian-u. Aptian & Green gray shale & 441 & 0.14 & 30 & & 30 & 10 & 30 & & & \\
\hline 17-2, Top & Maestrichtian-u. Aptian & Dark gray shale & 478 & 0.52 & 30 & 20 & 30 & 10 & & & 10 & \\
\hline 18-2, Top & Maestrichtian-u. Aptian & Dark gray shale & 526 & 0.23 & 50 & 10 & 30 & 10 & & & & \\
\hline $19-2,20$ & Maestrichtian-u. Aptian & Dark gray shale & 575 & 0.98 & 40 & 20 & 20 & 10 & & & 10 & \\
\hline $20-1,80$ & Maestrichtian-u. Aptian & Dark gray shale & 611 & 0.48 & 50 & 20 & 20 & 10 & & & & \\
\hline $20-3,23$ & Maestrichtian-u. Aptian & Dark gray shale & 615 & 0.78 & 40 & 20 & 30 & 10 & & & & \\
\hline $21-2,50$ & Maestrichtian-u. Aptian & Dark gray shale & 670 & 0.50 & 50 & 20 & 20 & 10 & & & & \\
\hline $22-2,50$ & Maestrichtian-u. Aptian & Dark gray shale & 717 & 0.15 & 20 & 20 & & & 60 & & & \\
\hline $23-2,100$ & Maestrichtian-u. Aptian & Dark gray to black shale & 766 & 2.03 & 20 & 10 & 20 & 10 & 40 & & & \\
\hline $23-4,50$ & Maestrichtian-u. Aptian & Dark gray to black shale & 768 & 0.28 & 40 & 10 & 40 & & 10 & & & \\
\hline $24-1,50$ & Maestrichtian-u. Aptian & Dark gray shale & 811 & 0.30 & 40 & 10 & 20 & 10 & 10 & & 10 & \\
\hline $25-1,50$ & Maestrichtian-u. Aptian & Med. blue gray shale & 860 & 0.09 & 30 & & 20 & 10 & 40 & & & \\
\hline $25-5,40$ & Maestrichtian-u. Aptian & Med. blue gray shale & 863 & 0.08 & 10 & & 20 & & 70 & & & \\
\hline $26-1,110$ & Maestrichtian-u. Aptian & Dusky red shale & 908 & 0.08 & 30 & & 20 & & 50 & & & \\
\hline $26-5,120$ & Albian & Dusky red shale & 910 & 0.15 & 10 & & 20 & & 70 & & & \\
\hline $27-2,110$ & Albian & Dark gray shale & 955 & 0.36 & 40 & 20 & 20 & & 10 & & 10 & \\
\hline $28-2,10$ & Lower Cretaceous & Grayish black shale & 1002 & 3.42 & 10 & & 10 & & 70 & 10 & & \\
\hline $28-6,20$ & Lower Cretaceous & Grayish black shale & 1006 & 1.89 & 10 & & 10 & & 60 & & & 20 \\
\hline $29-1,20$ & Lower Cretaceous & Black shale & 1029 & 3.42 & 20 & 10 & 20 & 10 & 40 & & & \\
\hline $29-6,20$ & Lower Cretaceous & Black shale & 1036 & 5.79 & 30 & 10 & 10 & 10 & 40 & & & \\
\hline $30-1,60$ & Lower Cretaceous & Black shale & 1039 & 21.70 & 10 & & 10 & & 70 & & & 10 \\
\hline $30-3,50$ & Lower Cretaceous & Green gray sandy mudstone & 1048 & 0.74 & 40 & 10 & 20 & 20 & 10 & & & \\
\hline $31-2,40$ & Lower Cretaceous & Greenish gray shale & 1049 & 0.90 & 20 & 10 & 20 & 10 & 40 & & & \\
\hline $31-4,110$ & Lower Cretaceous & Black shale & 1056 & 5.45 & 20 & 10 & 30 & 10 & 30 & & & \\
\hline $32-2,100$ & Lower Cretaceous & Greenish black mudstone & 1058 & 0.73 & 30 & 10 & 20 & 10 & 30 & & & \\
\hline $32-6,17$ & Lower Cretaceous & Black shale & 1065 & 4.26 & 20 & 10 & 10 & & 60 & & & \\
\hline $33-3,40$ & Aptian & Black shale & 1075 & 7.71 & 5 & 5 & & & 90 & & & \\
\hline $34-2,50$ & Aptian & Black shale & 1078 & 2.74 & 40 & 10 & 20 & & 30 & & & \\
\hline $34-4,130$ & Aptian & Black shale & 1083 & 7.95 & 10 & 10 & & & 80 & & & \\
\hline $37-2,30$ & Aptian & Black shale & 1106 & 2.95 & 40 & 10 & 30 & 10 & 10 & & & \\
\hline $38-2,60$ & Aptian & Black shale & 1116 & 2.08 & 50 & 10 & 30 & & 10 & & & \\
\hline $39-1,100$ & Aptian & Dark green gray mudstone & 1125 & 2.08 & 40 & & 30 & 10 & 20 & & & \\
\hline $40-1,80$ & Aptian & Black shale & 1143 & 3.78 & 10 & & 10 & 10 & 70 & & & \\
\hline $40-4,110$ & Aptian & Black shale & 1150 & 1.92 & 20 & & 10 & & 70 & & & \\
\hline $41-1,60$ & Aptian & Dark green gray sandy mudstone & 1165 & 0.40 & 50 & & 20 & 20 & 10 & & & \\
\hline $41-4,70$ & Aptian & Black shale & 1170 & 3.20 & 20 & 10 & 10 & & 60 & & & \\
\hline $42-1,50$ & Aptian & Black shale & 1182 & 8.05 & 10 & & 10 & & 80 & & & \\
\hline $43-1,50$ & Aptian & Greenish black sandy mudstone & 1202 & 0.40 & 40 & 10 & 30 & 10 & 10 & & & \\
\hline $44-4,130$ & Aptian & Black shale & 1222 & 2.34 & 40 & 10 & 20 & 10 & 20 & & & \\
\hline $44-3,100$ & Aptian & Black shale & 1226 & 2.43 & 40 & 10 & 20 & 10 & 20 & & & \\
\hline $45-2,100$ & Aptian & Black shale & 1241 & 1.18 & 50 & & 30 & 10 & 10 & & & \\
\hline $46-1,100$ & Aptian & Black shale & 1258 & 1.62 & 40 & & 30 & 10 & 20 & & & \\
\hline $47-1,65$ & Aptian & Black shale & 1267 & 4.39 & 20 & 10 & 30 & & 40 & & & \\
\hline $48-2,50$ & Aptian & Black shale & 1285 & 2.60 & 20 & 10 & 30 & & 40 & & & \\
\hline
\end{tabular}

Note: $\mathrm{S}$. terr. = structured terrestrial; $\mathrm{P} \& \mathrm{~S}=$ pollen \& spores; $\mathrm{C}=$ coaly; Bio. $\mathrm{t} .=$ biodegraded terrestrial; $\mathrm{AM}=$ amorphous; $\mathrm{GA}=\mathrm{gray}$ amorphous; $\mathrm{SM}=$ structured marine; $\mathrm{RB}=$ round bodies. Blank space $=$ none present.

The geologic setting of the Mid-Jurassic through mid-Cretaceous South Atlantic is one of an ocean divided into two basins by the high standing Rio Grande Rise and Walvis Ridge. It was separated from the North Atlantic Ocean by the still connected South American and African continents, and closed to the south by the Algulhas Fracture Zone Sill (Arthur and Natland, 1979; Sclater et al., 1977) (Fig. 8).

The kerogen record of sediments recovered by DSDP in the South Atlantic begins in Mid-Jurassic coastal plain sediments on the Falkland Plateau. These and the Late Jurassic shelfal sediments are terrestrial-rich and TOC-poor, reflecting their proximity to the land mass. The Late Jurassic sediments were deposited in a restricted basin in water less than $\mathbf{4 0 0} \mathrm{m}$ deep. Gradual restriction in circulation continued from the Late Jurassic to the Oxfordian (Barker and Dalziel, 1977). This accounts for the amorphous TOC enrichment in the Late Jurassic sediments. On the Falkland Plateau, a hiatus separates the Late Jurassic from late Neocomian-Aptian sediments (Thompson, 1977). While Aptian sediments were deposited on the Falkland Plateau, concurrent deposition occurred in the $2000 \mathrm{~m}$ deep Cape Basin to the north (Natland, 1978). Here, pelagic deposition of amorphous material was periodically interrupted by TOCpoor turbidity currents derived from the Orange River containing organic terrestrial material. The climate in the region of the Aptian Cape Basin was dry and/or cold, resulting in the restricted plant community (McLachlan and Pieterse, 1978). Natland (1978) inferred from their data and his own that the coast was swampy, with ferns and Classopollis, a possible mangrove type plant, filling the coastal areas. This served as the source of much of the terrestrial material at Site 361. Swampy conditions may have resulted in part from a rising sea level during the lower Aptian, which flooded the low lying area (Fig. 3).

Concurrent deposition north of the high-standing Walvis Ridge in the Angola Basin was also dominated by amorphous-rich sediments. These sediments are considerably richer in organic matter than those in the southern basins, with TOC values up to $24.3 \%$. This may be the result of high productivity (Melguen, 1978) and rapid sedimentation rates of $42.2 \mathrm{~m} / \mathrm{m} . \mathrm{y}$. (Bolli, Ryan et al., 1978). Morgan (1978) suggested that this site was some distance from shore in a low energy envi- 

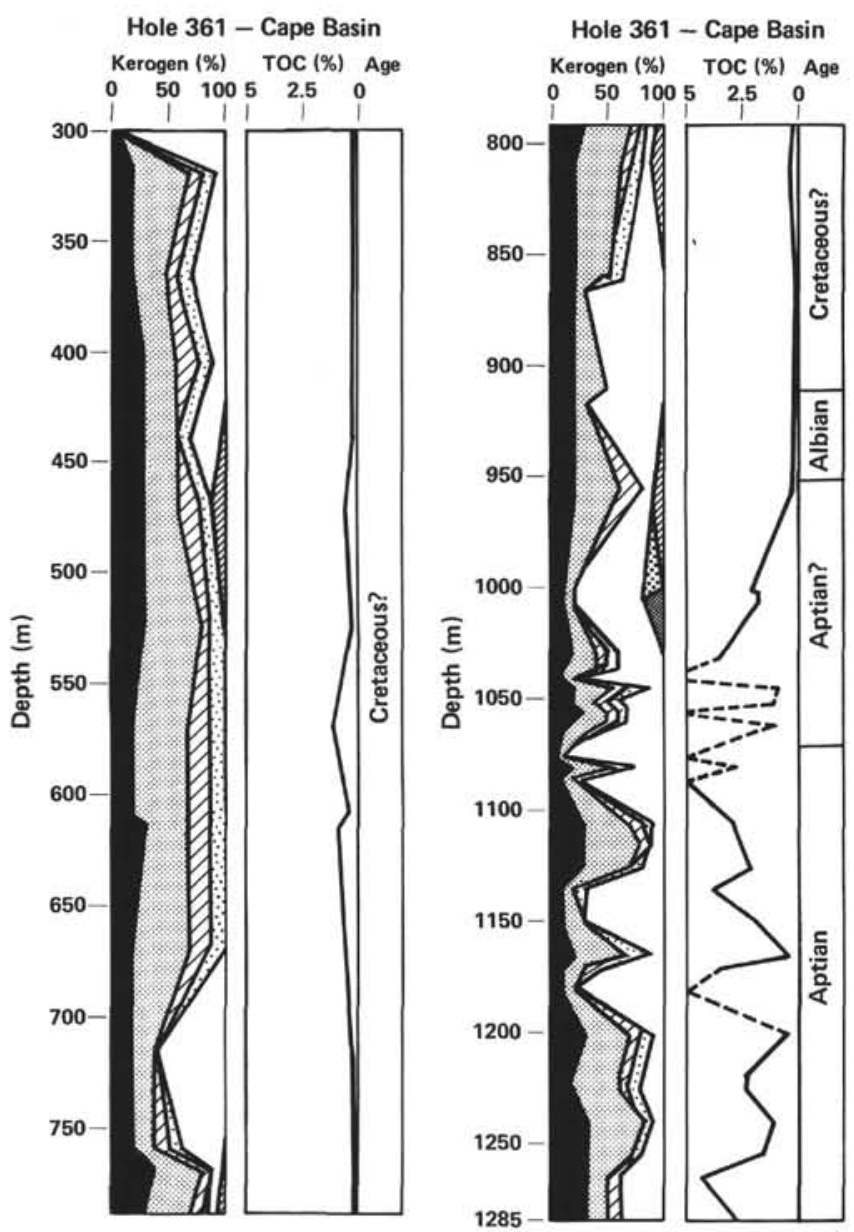

Figure 4. Kerogen, TOC, and age of sediments in the Cape Basin.

ronment and that the climatic conditions were hot and semi-arid. This climate may have precluded development of dense vegetation onshore and may explain why little terrestrial material is observed in the section.

Theories accounting for the preservation of organic matter in these sediments include density stratification in a restricted basin (Arthur and Natland, 1979) (Fig. 9) and the presence of an oxygen minimum zone (Ryan and Cita, 1977). Arthur and Natland's (1979) model of a restricted basin coupled with salinity stratification is certainly plausible in light of the narrow basins depicted in Figure 8 by Sclater et al. (1977), and the large variation in paleowater depths where anoxic sediments occur in the Cape Basin and the Falkland Plateau. A general rise in sea level from the Late Jurassic through early Aptian may have played a role in the development of anoxic conditions (Fig. 3). Transgressions may trigger high organic productivity and in turn depletion of oxygen in the water column (Tissot, 1979).

Whatever the cause of anoxic conditions in the early history of the South Atlantic, it was terminated effectively and uniformly across the southern basins during the late Aptian. The organic facies profiles from the Falkland Plateau and the Cape Basin indicate a rapid change to more oxidizing conditions as witnessed by the dramatic rise in the proportion of terrestrial organic matter and the reduction in TOC. Arthur and Natland (1979) attribute this change to oxidizing conditions resulting from the lowering of the Algulhas Fracture Zone Sill. This allowed the passage of shallow water over the sill and also over the Walvis Ridge and the Rio Grande Rise.

It is also likely that the late Aptian regression (Fig. 3) is important in influencing the kerogen profiles. With lower sea level, there was increased erosion and runoff from the continents, depositing large amounts of terrestrial material. The Aptian-Albian break in the kerogen profile is not as apparent in the Angola Basin, possibly because of a harsh and dry climate which inhibited the formation of dense vegetation. Consequently, there would have been less terrestrial material deposited during the regression.

The second period of organic enrichment is only present in sediments from the northern part of the South Atlantic Basin, the São Paulo Plateau, and the Angola Basin sites. The period is more extensive in the Angola $\mathrm{Ba}$ sin, lasting from the late Albian (Hole 530A) to the Santonian (Site 364). Organic-rich sediments were recovered only from the Turonian of the Sao Paulo Plateau. In fact, the abundance of TOC-poor, terrestrial-rich sediments from the Coniacian to the Santonian at Site 357 on the São Paulo Plateau indicates that the anoxic conditions noted by Bolli, Ryan et al. (1978) did not exist through the Santonian. Much of the organic matter at this site was probably derived from increased runoff associated with the uplift of the Andean Cordillera and the Sierra do Mar mountain range.

The kerogen and lithologies in the Angola Basin vary from amorphous, TOC-rich black shales to bioturbated, terrestrial rich, TOC-poor red shales. Bioturbated green shales are present in the sequence; those with more than $0.4 \%$ TOC are amorphous-rich while those with less than $0.4 \%$ TOC are terrestrial-rich. The variation in sediment color from red to green to black reflects changes in the oxidation state of iron related to oxygen levels in the water column (Meyers, this volume). Meyers (this volume) suggests that there was a delicate balance between oxidizing and reducing conditions in the Angola Basin at this time. Kerogen and TOC data support this concept. It is likely that organic productivity remained constant over the time interval in which these sediments were deposited and that only the oxygen concentration in the water column varied. These fluctuations would cause destruction or preservation of the more labile organic matter types, ultimately affecting the overall kerogen assemblage.

The organic facies data favor the presence of a midwater oxygen minimum on the northern South Atlantic during the late Albian through Santonian for several reasons. First, sediment color and organic-matter variations at Hole $530 \mathrm{~A}$ are best explained by a fluctuating oxygen-poor water mass whose lower limit periodically impinges on the sediments. Second, the São Paulo Plateau site is about $1000 \mathrm{~m}$ deeper than Angola Basin Site 364 (Arthur and Natland, 1979) and with the exception of the Turonian, the sediments are oxidized. One would expect that the sediments in a stratified or restricted 
Table 6. Lithology, total organic carbon, and kerogen distribution of samples from Site 364.

\begin{tabular}{|c|c|c|c|c|c|c|c|c|c|c|c|c|}
\hline \multirow{2}{*}{$\begin{array}{l}\text { Core-Section } \\
\text { (level in } \mathrm{cm})\end{array}$} & \multirow[b]{2}{*}{ Age } & \multirow[b]{2}{*}{ Lithology } & \multirow{2}{*}{$\begin{array}{l}\text { Depth } \\
\text { (m) }\end{array}$} & \multirow{2}{*}{$\begin{array}{l}\text { TOC } \\
(\%)\end{array}$} & \multicolumn{8}{|c|}{ Kerogen distribution } \\
\hline & & & & & S. terr. & P \& S & C & Bio. t. & AM & GA & SM & RB \\
\hline $11-1,100$ & Maestrichtian & Yellow calcareous nannofossil chalk & 359 & 0.08 & 50 & 10 & 20 & & 10 & & 10 & \\
\hline $13-1,100$ & Campanian & $\begin{array}{l}\text { Pale brown calcareous nannofossil } \\
\text { chalk }\end{array}$ & 397 & 0.06 & 10 & & 10 & & 70 & & 10 & \\
\hline $14-2,100$ & Campanian & $\begin{array}{l}\text { Reddish yellow calcareous nanno- } \\
\text { fossil chalk }\end{array}$ & 427 & 0.05 & 10 & & 10 & & 80 & & & \\
\hline $15-4,100$ & Campanian & $\begin{array}{l}\text { Reddish yellow calcareous nanno- } \\
\text { fossil chalk }\end{array}$ & 467 & 0.02 & 10 & & 10 & & 80 & & & \\
\hline $16-2,103$ & Campanian & $\begin{array}{l}\text { Light brown marly nannofossil } \\
\text { chalk }\end{array}$ & 503 & 0.06 & 10 & & 10 & & 80 & & & \\
\hline $17-1,100$ & Coniacian-Santonian & Brown calcareous nannofossil chalk & 531 & 0.05 & & & 10 & & 90 & & & \\
\hline $19-3,120$ & Coniacian-Santonian & Brown calcareous nannofossil chalk & 571 & 0.07 & 10 & & 10 & & 70 & & 10 & \\
\hline $20-1,120$ & Coniacian-Santonian & Green gray calc. nannofossil chalk & 578 & 0.05 & & & 10 & & 50 & 40 & & \\
\hline $20-4,120$ & Coniacian-Snatonian & Green gray calc. nannofossil chalk & 580 & 0.32 & & & 30 & & 50 & & 20 & \\
\hline $21-1,50$ & Coniacian-Santonian & Brown marly chalk & 597 & 0.09 & 10 & & 10 & & 80 & & & \\
\hline $21-5,35$ & Coniacian-Santonian & Grayish brown sapropel & 600 & 23.40 & 10 & & 10 & 10 & 70 & & & \\
\hline $22-2,100$ & Coniacian-Santonian & Green gray marly chalk and mudstone & 617 & 0.25 & 10 & & 20 & & 70 & & & \\
\hline $22-4,60$ & Coniacian-Santonian & Green gray marly chalk and mudstone & 623 & 0.17 & 10 & & 30 & & 40 & & 20 & \\
\hline $23-1,60$ & Coniacian-Santonian & Greenish gray mudstone & 645 & 1.36 & 10 & & 10 & & 70 & & 10 & \\
\hline $23-4,120$ & Coniacian-Santonian & Black shale & 652 & 2.89 & 10 & & 10 & & 80 & & & \\
\hline $24-1,65$ & Coniacian-Santonian & Black sapropelic shale & 673 & 11.29 & 10 & & 10 & & 80 & & & \\
\hline $25-1,100$ & Coniacian-Santonian & Green gray marly nannofossil chalk & 701 & 0.21 & 20 & & 30 & & 50 & & & \\
\hline $25-6,100$ & Coniacian-Santonian & Green gray marly nannofossil chalk & 708 & 0.19 & 50 & & 20 & & 10 & 10 & 10 & \\
\hline $26-1,100$ & Coniacian-Santonian & Green gray marly nannofossil chalk & 711 & 0.15 & 10 & & 20 & & 70 & & & \\
\hline $29-1,100$ & Albian & Blue gray limestone & 769 & 0.11 & 40 & 10 & 20 & & 10 & & 20 & \\
\hline $31-2,100$ & Albian & Blue gray limestone & 808 & 0.59 & 10 & & 10 & & 30 & & 30 & 20 \\
\hline $33-1,100$ & Albian & Blue gray limestone & 846 & 0.06 & 40 & & 30 & & 10 & 10 & 10 & \\
\hline $34-1,80$ & Albian & Blue gray limestone & 875 & 0.63 & 10 & & 10 & & 50 & & 10 & 20 \\
\hline $36-1,110$ & Albian & Blue gray limestone & 911 & 0.19 & 10 & & 10 & & 60 & & & 20 \\
\hline $37-1,100$ & Albian & Blue gray limestone & 931 & 0.47 & 20 & 10 & 10 & & 20 & & & 40 \\
\hline $37-4,35$ & Albian & Olive gray marly limestone & 935 & 1.24 & 10 & & 10 & & 60 & & & 20 \\
\hline $38-1,100$ & Albian & Olive gray marly limestone & 950 & 0.32 & 10 & & 10 & & 20 & & 10 & 50 \\
\hline $38-6,100$ & Albian & Olive gray marly limestone & 956 & 1.13 & 10 & & 10 & & 40 & & & 40 \\
\hline $39-1,100$ & 1. Albian-u. Aptian & Black sapropelic shale & 967 & 3.61 & 10 & & & & 90 & & & \\
\hline $39-6,100$ & 1. Albian-u. Aptian & Olive gray marly limestone & 975 & 2.17 & 10 & & & & 80 & & & 10 \\
\hline $40-2,100$ & 1. Albian-u. Aptian & Black sapropelic shale & 988 & 6.38 & 10 & & & 10 & 60 & & 10 & 10 \\
\hline $40-5,100$ & 1. Albian-u. Aptian & Olive gray marly limestone & 994 & 7.89 & & & 10 & & 70 & & & 20 \\
\hline $41, \mathrm{CC}$ & 1. Albian-u. Aptian & Black shale & & 0.57 & & & 10 & 10 & 50 & & & 30 \\
\hline $42-1,80$ & 1. Albian-u. Aptian & Blue gray marly dolomitic limestone & 1006 & 0.03 & 10 & & 10 & & 60 & & & 20 \\
\hline $42-6,32$ & 1. Albian-u. Aptian & Black shale & 1032 & 24.30 & & & 10 & & 90 & & & \\
\hline $43-1,50$ & 1. Albian-u. Aptian & Black shale & 1035 & 14.57 & & & 10 & 10 & 80 & & & \\
\hline $44-2,55$ & 1. Albian-u. Aptian & Black shale & 1047 & 1.50 & & & 10 & 10 & 80 & & & \\
\hline $45-1,120$ & 1. Albian-u. Aptian & Black shale & 1064 & 16.79 & & & 10 & 10 & 80 & & & \\
\hline
\end{tabular}

Note: $\mathrm{S}$. terr. = structured terrestrial; $\mathrm{P} \& \mathrm{~S}=$ pollen \& spores; $\mathrm{C}=$ coaly; Bio. $\mathrm{t}$. = biodegraded terrestrial; $\mathrm{AM}=$ amorphous; $\mathrm{GA}=$ gray amorphous; $\mathrm{SM}=$ structured marine; $\mathrm{RB}=$ round bodies. Blank space $=$ none present.

basin with little or no circulation would be reducing throughout the deepest part of the basin. However, Thiede and van Andel (1977) have noted that there are no reduced sediments below $3 \mathrm{~km}$ in the northern South Atlantic. Therefore, Turonian organic-rich sediments on the São Paulo Plateau may best be explained by the high sea level, which increased primary productivity and led to an expansion of the oxygen minimum layer (Tissot, 1979).

\section{CONCLUSIONS}

The organic facies data presented in this chapter indicate that two distinct periods of organic enrichment occurred in the Mesozoic of the South Atlantic, from the Late Jurassic through late Aptian and the late Albian through Santonian. Organic facies and lithologic descriptions coupled with good geologic control indicate that there were two main causes of anoxia. Salinity stratification was important during the earlier period, and the development of an oxygen minimum was important during the later period.

The organic facies data indicate a causal relationship between rising sea level and organic-rich rocks. Fluctuations in sea level may have played a part in: (1) the development of anoxic conditions in the Early Cretaceous; (2) the large influx of TOC-poor, terrestrial-rich material in the late Aptian-Albian; and (3) the development of the Turonian anoxic sediments at the Sáo Paulo Plateau.

The organic facies history of the South Atlantic is intimately tied to the climate which determined the type of organic material available for deposition. Sea level fluctuations influenced the rate at which organic matter was deposited as well as productivity and oxygen levels in the water column.

\section{ACKNOWLEDGMENTS}

I thank R. J. Pokluda, F. M. Weaver, and P. A. Meyers for their help in collecting samples and J. P. Shannon, Jr., C. P. Summerhayes, W. A. Young, D. L. Johnson, and R. Cunningham, Jr. for reviewing this manuscript. TOCs were determined by GeoChem Laboratories and EPRCo; E. B. Brown did the pyrolysis analysis; and I made the kerogen descriptions. I thank Exxon Production Research Company for permission to publish these results.

\section{REFERENCES}

Arthur, M. A., and Natland, J. H., 1979, Carbonaceous sediments in the North and South Atlantic: The role of salinity in stable stratification of Early Cretaceous basins. In Talwani, M., Hay, W., and Ryan, W. B. F. (Eds.), Deep Drilling in the Atlantic Ocean: Continental Margins and Paleoenvironment: Washington, Am. Geophys. Union, Maurice Ewing Ser., 3:375-401.

Barker, P. F., Dalziel, I. W. D., et al., 1977. Init. Repts. DSDP, 36: Washington (U.S. Govt. Printing Office).

Bolli, H. M., Ryan, W. B. F., et al., 1978. Init. Repts. DSDP, 40: Washington (U.S. Govt. Printing Office).

McLachlan, I. R., and Pieterse, E., 1978. Preliminary palynological results: Site 361, Leg 40, Deep Sea Drilling Project. In Bolli, H. 
Table 7. Lithology, total organic carbon, and kerogen distribution of samples from Hole 530A.

\begin{tabular}{|c|c|c|c|c|c|c|c|c|c|c|c|c|c|c|}
\hline \multirow{2}{*}{$\begin{array}{l}\text { Core-Section } \\
\text { (interval in cm) }\end{array}$} & \multirow[b]{2}{*}{ Age } & \multirow[b]{2}{*}{ Lithology } & \multirow{2}{*}{$\begin{array}{l}\text { Depth } \\
\text { (m) }\end{array}$} & \multirow{2}{*}{$\begin{array}{l}\text { TOC } \\
(\%)\end{array}$} & \multirow[b]{2}{*}{ TAI } & \multicolumn{9}{|c|}{ Kerogen distribution } \\
\hline & & & & & & S. terr. & $P \& S$ & C & Bio. t. & $\mathrm{AM}$ & GA & SM & RB & IF \\
\hline $86-5,31-32$ & Santonian & Black claystone & 937.5 & 1.28 & 1.3 & & & & & 80 & & & 10 & 10 \\
\hline $86-4,145-147$ & Santonian & Green claystone & 937.0 & 0.28 & & & & & & & & & & \\
\hline $86-5,33$ & Santonian & Black claystone & 937.5 & 2.02 & & & & 10 & & 80 & & & 10 & \\
\hline $86-5,36$ & Santonian & Dark green claystone & 937.6 & 0.16 & & & & & & & & & & \\
\hline $87-1,37$ & Coniacian & Black shale & 940.5 & 5.37 & & & & 90 & & & & & 10 & \\
\hline $87-1,83$ & Coniacian & Black claystone & 941.0 & 1.31 & & 10 & 10 & 20 & & 30 & & & & 30 \\
\hline $87-3,83-85$ & Coniacian & Dark red claystone & 944.0 & 0.25 & & & & & & & & & & \\
\hline $87-4,105-106$ & Coniacian & Black shale & 945.6 & 6.22 & & & & & & 80 & & & & 20 \\
\hline $87-4,118-119$ & Coniacian & Green claystone & 945.7 & 0.16 & & & & 40 & & 60 & & & & \\
\hline $88-3,33$ & Coniacian & Black shale & 952.3 & 9.70 & & & & & & 90 & & & & \\
\hline $88-3,90$ & Coniacian & Black shale & 952.9 & 2.84 & & & & & & 90 & & & & \\
\hline $89-1,34$ & Coniacian & Black shale & 958.3 & 9.60 & & & & & & 90 & & & & \\
\hline $90-3,86-87$ & Coniacian & Black shale & 970.9 & 16.50 & & & & & & 90 & & & & \\
\hline $90-3,99-100$ & Coniacian & Gray marlstone & 971.0 & 0.62 & & 40 & & & & 60 & & & & \\
\hline $91-4,45$ & Coniacian & Green claystone & 981.0 & 1.19 & & & & & & & & & & \\
\hline $93-1,40$ & Coniacian & Green claystone & 990.4 & 0.95 & 2 & 40 & & & & 60 & & & & \\
\hline $93-2,35$ & Coniacian & Green shale & 991.8 & 0.18 & & 80 & & 10 & & 10 & & & & \\
\hline $93-3,45$ & Coniacian & Red claystone & 993.5 & 0.11 & & & & & & & & & & \\
\hline $94-1,42-43$ & Coniacian & Black shale & 999.4 & 12.66 & & 60 & & 40 & & & & & & \\
\hline $94-2,11-12$ & Coniacian & Dark green shale & 1000.6 & 0.35 & & & & & & & & & & \\
\hline $96-2,118-119$ & Cenomanian & Dark red claystone & 1019.7 & 0.11 & & & & & & & & & & \\
\hline $96-4,29-30$ & Cenomanian & Black shale & & 1.79 & & & & & & & & & & \\
\hline $96-4,61-62$ & Cenomanian & Black shale & 1022.1 & 5.82 & & & & & & 90 & & & & \\
\hline $97-3,59-60$ & Cenomanian & Black shale & 1029.6 & 7.29 & & & & & & 50 & & & & 50 \\
\hline $97-3,56-57$ & Cenomanian & & & & 2 & 10 & & & & 90 & & & & \\
\hline $97-4,56-57$ & Cenomanian & Black shale & 1013.1 & 8.04 & & & & & & 90 & & & & \\
\hline $98-2,60-61$ & Cenomanian & Dark green claystone & 1037.1 & 0.28 & & & & & & & & & & \\
\hline $98-2,69-70$ & Cenomanian & Black shale & 1037.2 & 1.44 & & 10 & & 10 & & 80 & & & & \\
\hline $98-3,92-93$ & Cenomanian & Black shale & 1038.9 & 8.57 & & & & & & 90 & & & & \\
\hline $98-3,110-111$ & Cenomanian & Dark green claystone & 1039.1 & 0.47 & 2 & 10 & 10 & & & 70 & & & & \\
\hline $99-5,70-71$ & Cenomanian & Black shale & 1050.7 & 1.73 & 2 & & & & & 90 & & & & \\
\hline $100-1,85-86$ & Cenomanian & Dark green shale & 1053.9 & 0.28 & & 60 & & 20 & & 20 & & & & \\
\hline $100-1,99-100$ & Cenomanian & Black shale & 1054.0 & 1.92 & & 10 & & & & 90 & & & & \\
\hline $100-4,114-115$ & Cenomanian & Dark green marlstone & 1058.6 & & & & & & & & & & & \\
\hline $100-5,38-39$ & Cenomanian & Dark red claystone & 1059.4 & 0.38 & & & & & & & & & & \\
\hline $101-1,16-17$ & Cenomanian & Green claystone & 1062.2 & 0.70 & & 20 & 10 & 20 & & 30 & & 20 & & \\
\hline $101-2,8-9$ & Cenomanian & Black shale & 1063.6 & 0.93 & & 60 & 10 & 20 & & 10 & & & & \\
\hline $101-4,36-37$ & Cenomanian & Dark green claystone & 1066.9 & 1.31 & & & & 10 & & 90 & & & & \\
\hline $101-4,55-56$ & Cenomanian & Light green marlstone & 1067.1 & 0.08 & & 10 & & 10 & & 80 & & & & \\
\hline $102-1,149-150$ & Cenomanian & Dark green claystone & 1072.5 & 1.16 & & & & 10 & 10 & 80 & & & & \\
\hline $102-3,120-121$ & Cenomanian & Black shale & 1075.2 & 1.73 & & 20 & & 70 & & 10 & & & & \\
\hline $102-3,130-131$ & Cenomanian & Dark green claystone & 1075.3 & 0.45 & & & & & & 90 & & & & \\
\hline $103-6,22-23$ & Cenomanian & Green claystone & 1085.7 & 0.16 & & 10 & & & & 90 & & & & \\
\hline $104-2,141-142$ & Albian & Dark green claystone & 1087.9 & 0.41 & & 20 & & 70 & & 10 & & & & \\
\hline $104-3,0-1$ & Albian & Black claystone & 1088.0 & 8.21 & & & & & & & & & & \\
\hline $104-4,123-124$ & Albian & Dark green claystone & 1090.7 & 0.18 & & & & & & & & & & \\
\hline $104-4,91-92$ & Albian & Green claystone & 1090.4 & 0.47 & & & & & & & & & & \\
\hline $104-5,61-62$ & Albian & Black claystone & 1091.6 & 0.57 & & & & & & & & & & \\
\hline $\begin{array}{l}105-1,23-24 \\
105-2,139-140\end{array}$ & $\begin{array}{l}\text { Albian } \\
\text { Albian }\end{array}$ & Dark green claystone & 1094.2 & 0.23 & & 50 & & 20 & & $\begin{array}{l}30 \\
80\end{array}$ & & & & 20 \\
\hline $\begin{array}{l}105-2,139-140 \\
105-4,35-36\end{array}$ & $\begin{array}{l}\text { Albian } \\
\text { Albian }\end{array}$ & $\begin{array}{l}\text { Black shale } \\
\text { Light green limestone }\end{array}$ & $\begin{array}{l}1096.9 \\
1098.9\end{array}$ & $\begin{array}{l}5.28 \\
0.44\end{array}$ & & & & 10 & & 90 & & & & \\
\hline $105-4,9-10$ & Albian & Black shale & 1098.6 & 3.60 & & & & & & 90 & & & & 10 \\
\hline
\end{tabular}

Note: $\mathrm{S}$. terr. = structured terrestrial; $\mathrm{P} \& \mathrm{~S}=$ pollen \& spores; $\mathrm{C}=$ coaly; Bio. $\mathrm{t}$. = biodegraded terrestrial; $\mathrm{AM}=$ amorphous; $\mathrm{GA}=\mathrm{gray}$ amorphous; $\mathrm{SM}=$ structured marine; $\mathrm{RB}=$ round bodies; $\mathrm{IF}=$ indeterminate fines. Blank space = none present.

M., Ryan, W. B. F., et al., Init. Repts. DSDP, 40: Washington (U.S. Govt. Printing Office), 857-881.

Masran, Th. C., and Pocock, S. A. J., 1981. The classification of plant derived particulate organic matter in sedimentary rocks. In Brooks, J. (Ed.), Organic Maturation Studies and Fossil Fuel Exploration, pp. 145-161.

Morgan, R., 1978. Albian to Senonian palynology of Site 364, Angola Basin. In Bolli, H. M., Ryan, W. B. F., et al., Init. Repts. DSDP, 40: Washington (U.S. Govt. Printing Office), 915-952.

Natland, J. H., 1978. Composition, provenance, and diagenesis of Cretaceous clastic sediments drilled on the Atlantic continental rise off Southern Africa, DSDP Site 361-Implications for the early circulation of the South Atlantic. In Bolli, H. N., Ryan, W. B. F., et al., Init. Repts. DSDP, 40: Washington (U.S. Govt. Printing Office), 1025-1062.

Ryan, W. B. F., and Cita, M. B., 1977. Ignorance concerning episodes of oceanwide stagnation. Mar. Geol., 23:197-215.

Sclater, J. G., Hellinger, S., and Tapscott, C., 1977. The paleobathymetry of the Atlantic Ocean from the Jurassic to the present. $J$. Geol., 85:509-552.

Supko, P. A., Perch-Nielsen, K., et al., 1977. Init. Repts. DSDP, 39: Washington (U.S. Govt. Printing Office).
Thompson, R. W., 1977. Mesozoic sedimentation on the Eastern Falkland Plateau. In Barker, P. F., Dalziel, I. W. D., et al., Init. Repts. DSDP, 36: Washington (U.S. Govt. Printing Office), 877-891.

Tissot, B., 1979. Effects on prolific petroleum source rocks and major coal deposits caused by sea level changes. Nature, 277:463-465.

Tissot, B., Demaison, G., Masson, P., Delteil, J. R., and Combaz, A., 1980. Paleonvironment and petroleum potential of middle Cretaceous black shales in the Atlantic basins. AAPG Bull., 64: 2051-2063.

Vail, P. R., Mitchum, R. M., Jr., and Thompson S., III, 1977. Seismic stratigraphy and global changes of sea level, part 4: Global cycles of relative changes of sea level. In Payton, C. E. (Ed.), Seismic Stratigraphy-Applications to Hydrocarbon Exploration. Am. Assoc. Pet. Geol. Mem., 26:83-97.

van Andel, Tj. H., Thiede, J., Slater, J. G., and Hay, W. W., 1977. Depositional history and paleo-oceanography of the South Atlantic during the last 125 million years. J. Geol., 85:651-698.

Date of Initial Receipt: September 24, 1982 

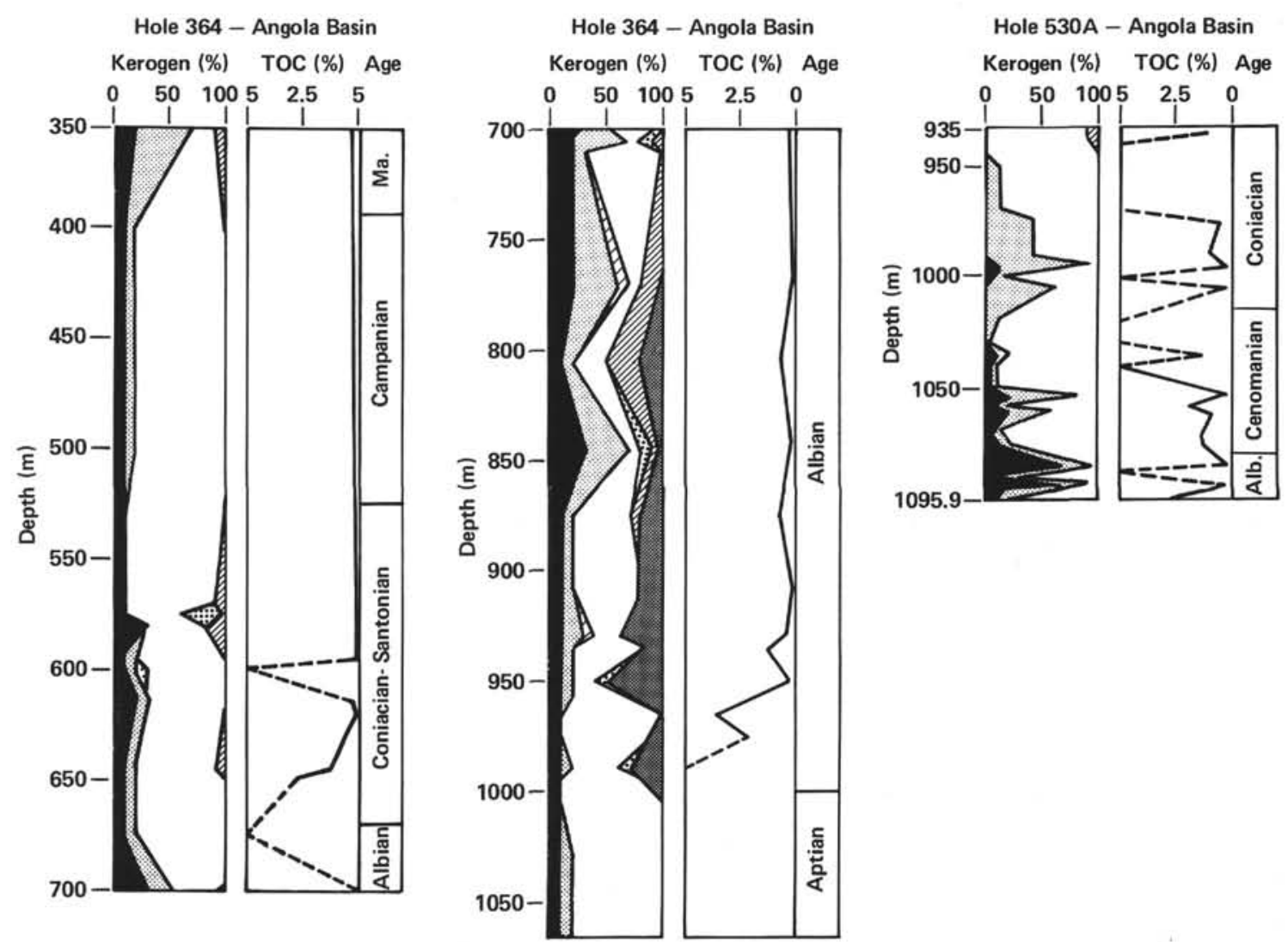

Figure 5. Kerogen, TOC, and age distributions of sediments on the Angola Basin.

Table 8. Lithology, total organic carbon, and kerogen distribution of samples from Site 363.

\begin{tabular}{|c|c|c|c|c|c|c|c|c|c|c|c|c|}
\hline \multirow{2}{*}{$\begin{array}{l}\text { Core-Section } \\
\text { (level in } \mathrm{cm})\end{array}$} & \multirow[b]{2}{*}{ Age } & \multirow[b]{2}{*}{ Lithology } & \multirow{2}{*}{$\begin{array}{l}\text { Depth } \\
\text { (m) }\end{array}$} & \multirow{2}{*}{$\begin{array}{l}\text { TOC } \\
(\%)\end{array}$} & \multicolumn{8}{|c|}{ Kerogen distribution } \\
\hline & & & & & S. terr. & $P \& S$ & $\mathrm{C}$ & Bio. t. & $\mathrm{AM}$ & GA & SM & RB \\
\hline $18-2,100$ & Maestrichtian & Brown gray nannofossil chalk & 326 & 0.16 & 10 & & 30 & & 60 & & & \\
\hline $23-2,100$ & Campanian & Gray nannofossil chalk & 390 & 0.10 & 30 & & 30 & & 40 & & & \\
\hline $24-1,1100$ & Campanian & Gray marly nannofossil chalk & 402 & 0.12 & 20 & 10 & 30 & 10 & 30 & & & \\
\hline $25-1,130$ & Coniac.-Santonian & Dark olive nannofossil chalk & 421 & 0.05 & 20 & 20 & 30 & & 30 & & & \\
\hline $26-1,100$ & Albian & Gray nannofossil chalk & 440 & 0.13 & 30 & 10 & 50 & & 10 & & & \\
\hline $26-4,100$ & Albian & Gray nannofossil chalk & 448 & 0.09 & 40 & 20 & 30 & & 10 & & & \\
\hline $27-1,100$ & Albian & Gray nannofossil chalk & 459 & 0.10 & 60 & & 20 & & 10 & & 10 & \\
\hline $28-1,100$ & Albian & Green gray marly limestone & 478 & 0.09 & 50 & 10 & 20 & & 10 & & 10 & \\
\hline $28-6,61$ & Albian & Green gray marly limestone & 485 & 0.14 & 80 & 10 & & & 10 & & & \\
\hline $29-1,101$ & Albian & Light gray marly limestone & 497 & 0.11 & 40 & & 20 & 20 & 10 & & 10 & \\
\hline $30-1,100$ & Albian & Light gray marly limestone & 516 & 0.10 & 60 & & 20 & & 10 & & 10 & \\
\hline $31-1,100$ & Albian & Light gray marly limestone & 535 & 0.12 & 60 & 10 & 30 & & & & & \\
\hline $31-6,67$ & Albian & Light gray marly limestone & 543 & 0.12 & 40 & 10 & 30 & & 10 & & 10 & \\
\hline $32-1,100$ & Albian & Light gray marly limestone & 554 & 0.12 & 40 & 10 & 30 & & 10 & & 10 & \\
\hline $33-1,130$ & Albian & Light gray marly limestone & 573 & 0.07 & 40 & & 40 & 10 & & & 10 & \\
\hline $36-3,102$ & Albian & Gray limestone & 630 & 0.07 & 40 & 10 & 40 & & & & 10 & \\
\hline $37-1,50$ & Aptian & Light gray limestone & 650 & 0.05 & 40 & 10 & 30 & & 10 & & 10 & \\
\hline $38-1,60$ & Aptian & Light gray limestone & 670 & 0.15 & 40 & 20 & 20 & & 10 & & 10 & \\
\hline $39-2,20$ & Aptian & Yellow gray limestone & 690 & 0.12 & 30 & 10 & 30 & & & & 30 & \\
\hline
\end{tabular}

Note: $\mathrm{S}$. terr. = structured terrestrial; $\mathrm{P} \& \mathrm{~S}=$ pollen \& spores; $\mathrm{C}=$ coaly; Bio. $\mathrm{t}$. = biodegraded terrestrial; $\mathrm{AM}=$ amorphous; $\mathrm{GA}=$ gray amorphous; $\mathrm{SM}=$ structured marine; $\mathrm{RB}=$ round bodies. Blank space $=$ none present. 


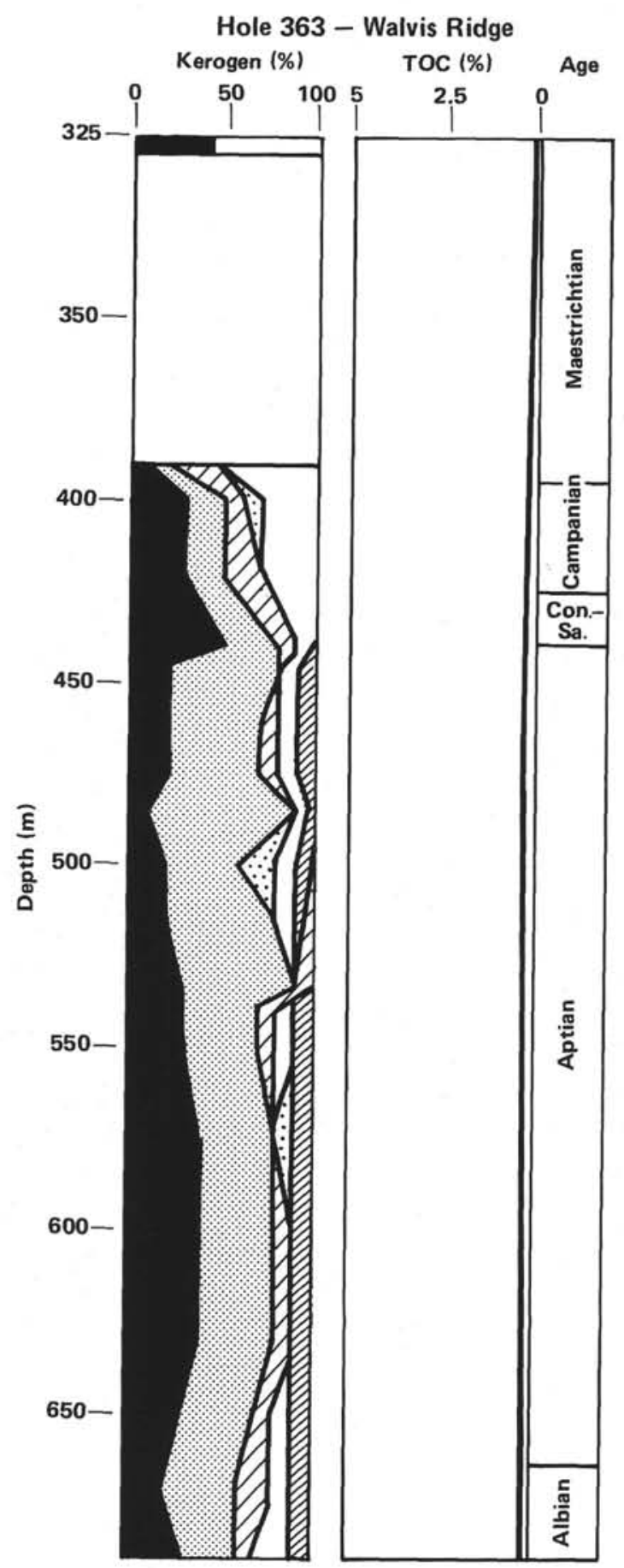

Figure 6. Kerogen, TOC, and age distributions of sediments on the Walvis Ridge. 
Table 9. Lithology, total organic carbon, and kerogen distribution of samples from Site 356.

\begin{tabular}{|c|c|c|c|c|c|c|c|c|c|c|c|c|}
\hline \multirow{2}{*}{$\begin{array}{l}\text { Core-Section } \\
\text { (level in } \mathrm{cm} \text { ) }\end{array}$} & \multirow[b]{2}{*}{ Age } & \multirow[b]{2}{*}{ Lithology } & \multirow{2}{*}{$\begin{array}{l}\text { Depth } \\
\text { (m) }\end{array}$} & \multirow{2}{*}{$\begin{array}{l}\text { TOC } \\
(\%)\end{array}$} & \multicolumn{8}{|c|}{ Kerogen distribution } \\
\hline & & & & & S. terr. & P \& S & C & Bio. t. & $\mathrm{AM}$ & GA & SM & RB \\
\hline $24-1,100$ & Paleocene & Green gray foram nanno clay & 361 & 0.20 & 20 & & 40 & & 40 & & & \\
\hline $26-4,100$ & Paleocene & Pinkish gray foram nanno chalk & 385 & 0.17 & 10 & & 10 & & 80 & & & \\
\hline $27-5,100$ & Paleocene & Pinkish gray foram nanno chalk & 391 & 0.15 & 10 & & 10 & & 80 & & & \\
\hline $28-4,104$ & Paleocene & Pinkish gray foram nanno chalk & 401 & 0.10 & 10 & & 10 & & 80 & & & \\
\hline $29-5,100$ & Maestrichtian & Pale yellow brown foram nanno chalk & 412 & 0.02 & 10 & & 10 & 10 & 70 & & & \\
\hline $30-1,100$ & Maestrichtian & Light blue gray foram nanno chalk & 418 & 0.07 & 10 & & 20 & & 70 & & & \\
\hline $31-1,100$ & Maestrichtian & Light gray marly nanno chalk & 437 & 0.04 & 10 & & 20 & & 70 & & & \\
\hline $32-2,100$ & Maestrichtian & Light gray marly calc. chalk & 457 & 0.05 & 10 & & 20 & & 70 & & & \\
\hline $33-1,100$ & Maestrichtian & Light gray marly calc. chalk & 486 & 0.09 & 10 & & 20 & & 70 & & & \\
\hline $34-1,100$ & Campanian & Olive gray marly calc. chalk & 515 & 0.04 & 20 & & 20 & & 60 & & & \\
\hline $35-1,100$ & Santonian & Olive gray dolomite marly calc. chalk & 542 & 0.10 & 10 & & 10 & & 80 & & & \\
\hline $36-1,100$ & Santonian & Med. dk. gray dolomite marly calc. chalk & 577 & 0.11 & 60 & & 30 & & 10 & & & \\
\hline $37-1,100$ & Santonian & Olive gray marly calc. chalk & 599 & 0.15 & 60 & & 30 & & 10 & & & \\
\hline $38-3,45$ & Santonian & Med. gray marly calc. chalk & 655 & 0.14 & 60 & & 30 & & 10 & & & \\
\hline $39-1,108$ & Coniacian & Light gray calc. mudstone & 675 & 0.08 & 60 & & 30 & & 10 & & & \\
\hline $40-3,100$ & Coniacian & Med. gray calc. mudstone & 700 & 0.08 & 10 & & 20 & & 70 & & & \\
\hline $41-2,70$ & Maestrichtian & Green gray dolomitic calc. mudstone & 704 & 2.99 & 10 & & 10 & & 80 & & & \\
\hline $41-4,75$ & Maestrichtian & Light blue gray limestone & 710 & 2.09 & 10 & & 10 & 10 & 70 & & & \\
\hline $42-1,100$ & Albian & Green brown calc. mudstone & 714 & 0.19 & 50 & & 40 & & 10 & & & \\
\hline $43-1,100$ & Albian & Med. dk. gray marly limestone & 723 & 0.11 & 40 & 10 & 40 & & & & 10 & \\
\hline $44-1,100$ & Albian & Med. dk. gray marly dolomitic limestone & 732 & 0.05 & 50 & & 40 & & 10 & & & \\
\hline
\end{tabular}

Note: $\mathrm{S}$. terr, = structured terrestrial; $\mathrm{P} \& \mathrm{~S}=$ pollen \& spores; $\mathrm{C}=$ coaly; Bio. $\mathrm{t}$. = biodegraded terrestrial; $\mathrm{AM}=$ amorphous; $\mathrm{GA}=\mathrm{gray}$ amorphous; $\mathrm{SM}=$ structured marine; $\mathrm{RB}=$ round bodies. Blank space $=$ none present.
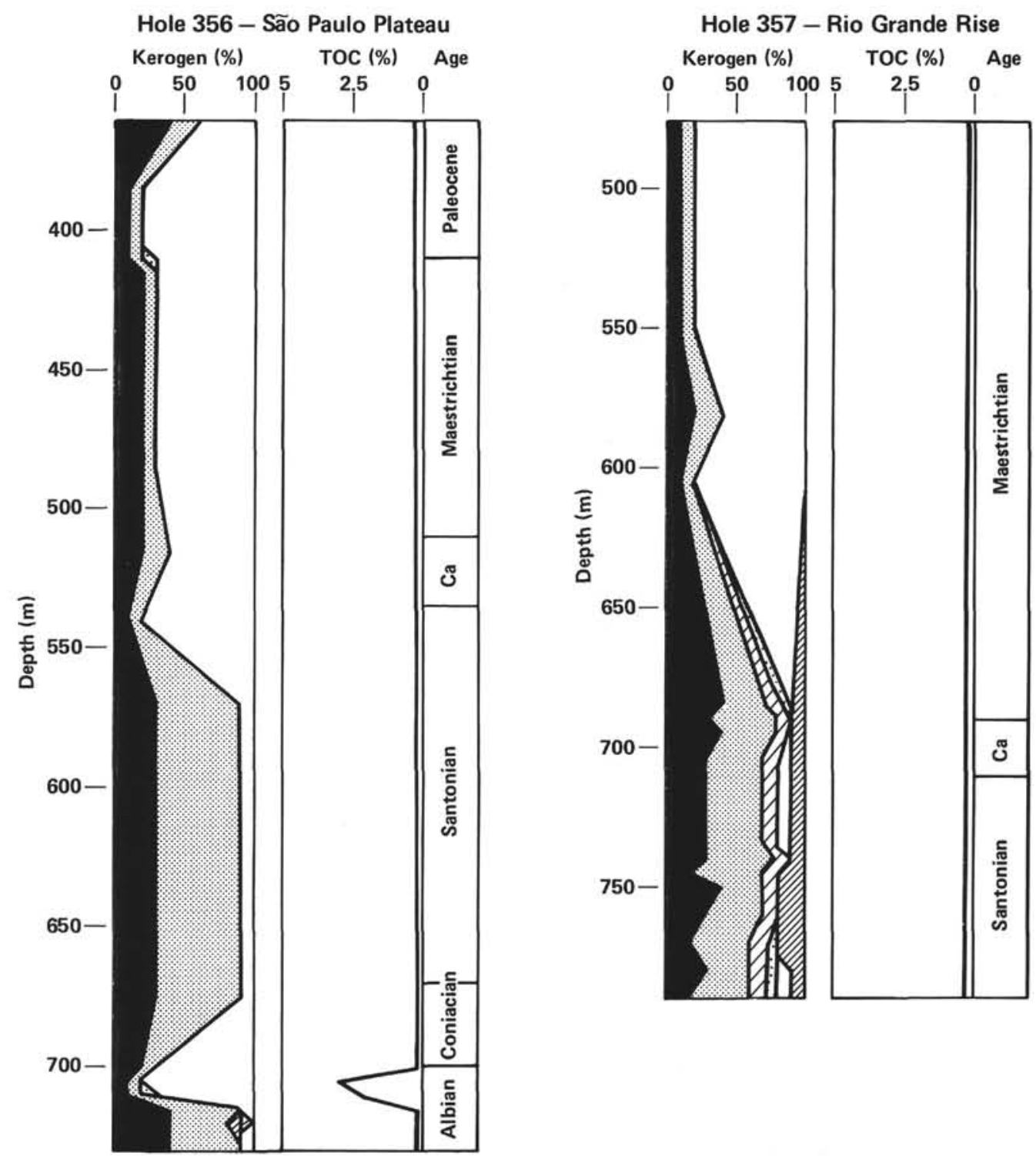

Figure 7. Kerogen, TOC, and age of sediments on the Rio Grande Rise and São Paulo Plateau. 
Table 10. Lithology, total organic carbon, and kerogen distribution of samples from Site 357.

\begin{tabular}{|c|c|c|c|c|c|c|c|c|c|c|c|c|}
\hline \multirow{2}{*}{$\begin{array}{l}\text { Core-Section } \\
\text { (level in } \mathrm{cm})\end{array}$} & \multirow[b]{2}{*}{ Age } & \multirow[b]{2}{*}{ Lithology } & \multirow{2}{*}{$\begin{array}{l}\text { Depth } \\
\text { (m) }\end{array}$} & \multirow{2}{*}{$\begin{array}{l}\text { TOC } \\
(\%)\end{array}$} & \multicolumn{8}{|c|}{ Kerogen distribution } \\
\hline & & & & & S. terr. & $P \& S$ & $\mathrm{C}$ & Bio. $t$. & AM & GA & SM & RB \\
\hline $30-1,100$ & Paleocene & Light brown limestone & 474 & 0.13 & 10 & & 10 & & 80 & & & \\
\hline $31-2,100$ & Maestrichtian & Pink gray limestone & 495 & 0.09 & 10 & & 10 & & 80 & & & \\
\hline $32-1,100$ & Maestrichtian & Light brown nanno chalk & 503 & 0.06 & 10 & & 10 & & 80 & & & \\
\hline $33-1,100$ & Maestrichtian & Brown nanno chalk & 522 & 0.11 & 10 & & 10 & & 80 & & & \\
\hline $34-1,100$ & Maestrichtian & Blue gray foram nanno chalk & 550 & 0.07 & 10 & & 10 & & 80 & & & \\
\hline $35-2,100$ & Maestrichtian & Brown nanno chalk & 580 & 0.07 & 20 & & 20 & & 60 & & & \\
\hline $36-1,100$ & Maestrichtian & Brown foram nanno chalk & 608 & 0.06 & 10 & & 10 & & 80 & & & \\
\hline $39-1,100$ & Campanian & Olive gray micrite chalk & 684 & 0.10 & 30 & 10 & 40 & 5 & 5 & & 10 & \\
\hline $40-1,100$ & Campanian & Olive gray micrite chalk & 693 & 0.11 & 50 & 10 & 30 & & & 10 & & \\
\hline $40-4,42$ & Campanian & Olive gray micrite chalk & 697 & 0.12 & 40 & 10 & 40 & & & & 10 & \\
\hline $41-1,105$ & Santonian & Green gray micritic chalk & 704 & 0.07 & 40 & 10 & 30 & & 10 & & 10 & \\
\hline $42-1,100$ & Santonian & Green gray micritic chalk & 714 & 0.10 & 40 & 10 & 30 & & 10 & & 10 & \\
\hline $43-1,105$ & Santonian & Green gray foram nanno limestone & 723 & 0.08 & 40 & 10 & 30 & & 10 & & 10 & \\
\hline $44-2,100$ & Santonian & Greenish gray marly limestone & 733 & 0.09 & 40 & 10 & 30 & 10 & & & 10 & \\
\hline $45-2,100$ & Santonian & Greenish gray marly limestone & 740 & 0.10 & 50 & 10 & & 30 & & & 10 & \\
\hline $46-2,100$ & Santonian & Greenish gray marly limestone & 745 & 0.10 & 50 & 10 & 20 & & & & 20 & \\
\hline $47-1,100$ & Santonian & Greenish gray marly chalk & 750 & 0.10 & 30 & 10 & 40 & & & & 20 & \\
\hline $48-1,100$ & Santonian & Greenish gray marly limestone & 760 & 0.10 & 40 & 10 & 30 & & & & 20 & \\
\hline $49-2,100$ & Santonian & Greenish gray marly limestone & 770 & 0.15 & 40 & 10 & 20 & 10 & & & 20 & \\
\hline $50-1,100$ & Santonian & Greenish gray siliceous marly limestone & 779 & 0.17 & 30 & 10 & 30 & 10 & 10 & & 10 & \\
\hline $51-1,100$ & Santonian & Greenish gray siliceous marly limestone & 788 & 0.08 & 40 & 10 & 20 & 10 & 10 & & 10 & \\
\hline
\end{tabular}

Note: $\mathrm{S}$. terr, $=$ structured terrestrial; $\mathrm{P} \& \mathrm{~S}=$ pollen \& spores; $\mathrm{C}=$ coaly; Bio, $\mathrm{t}$, = biodegraded terrestrial; $\mathrm{AM}=$ amorphous; $\mathrm{GA}=\mathrm{gray}$ amorphous; $\mathrm{SM}=$ structured marine; $\mathrm{RB}=$ round bodies. Blank space $=$ none present. 
D. GILBERT
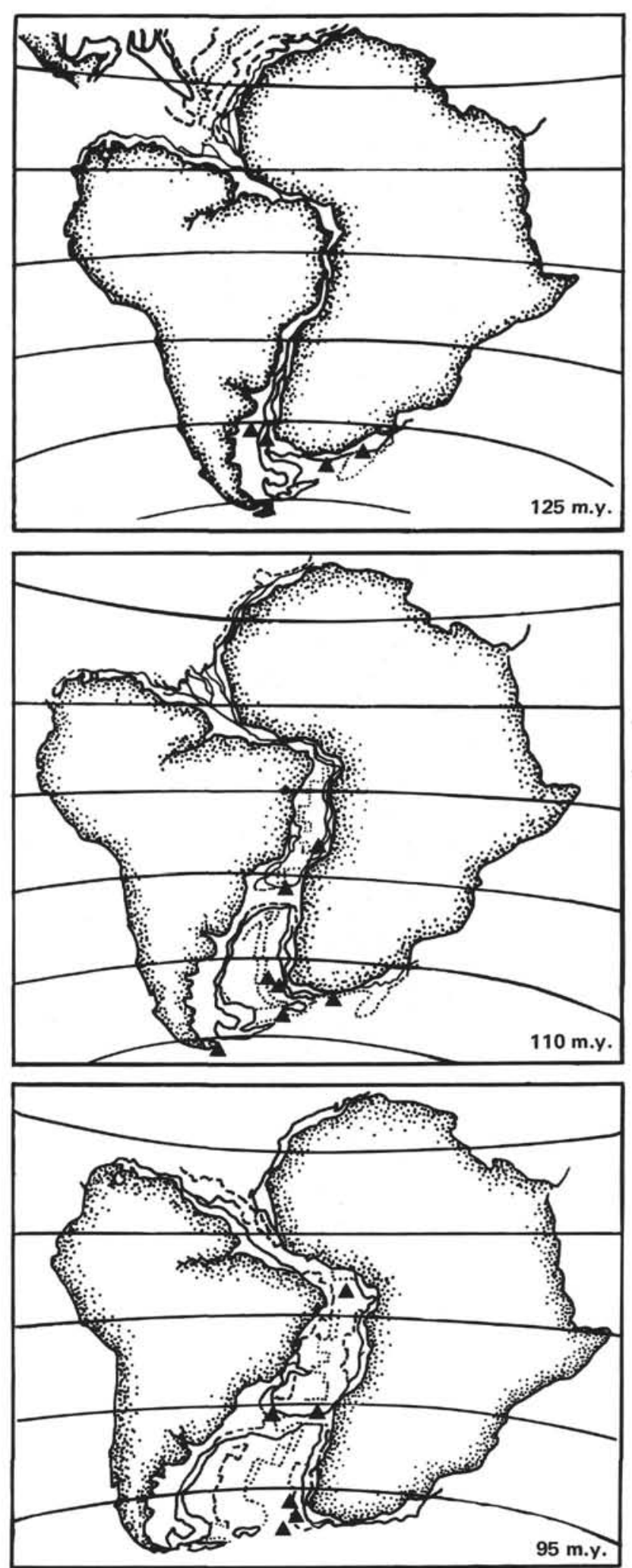

Figure 8. Paleoreconstructions of the Mesozoic South Atlantic (Sclater et al., 1977). 

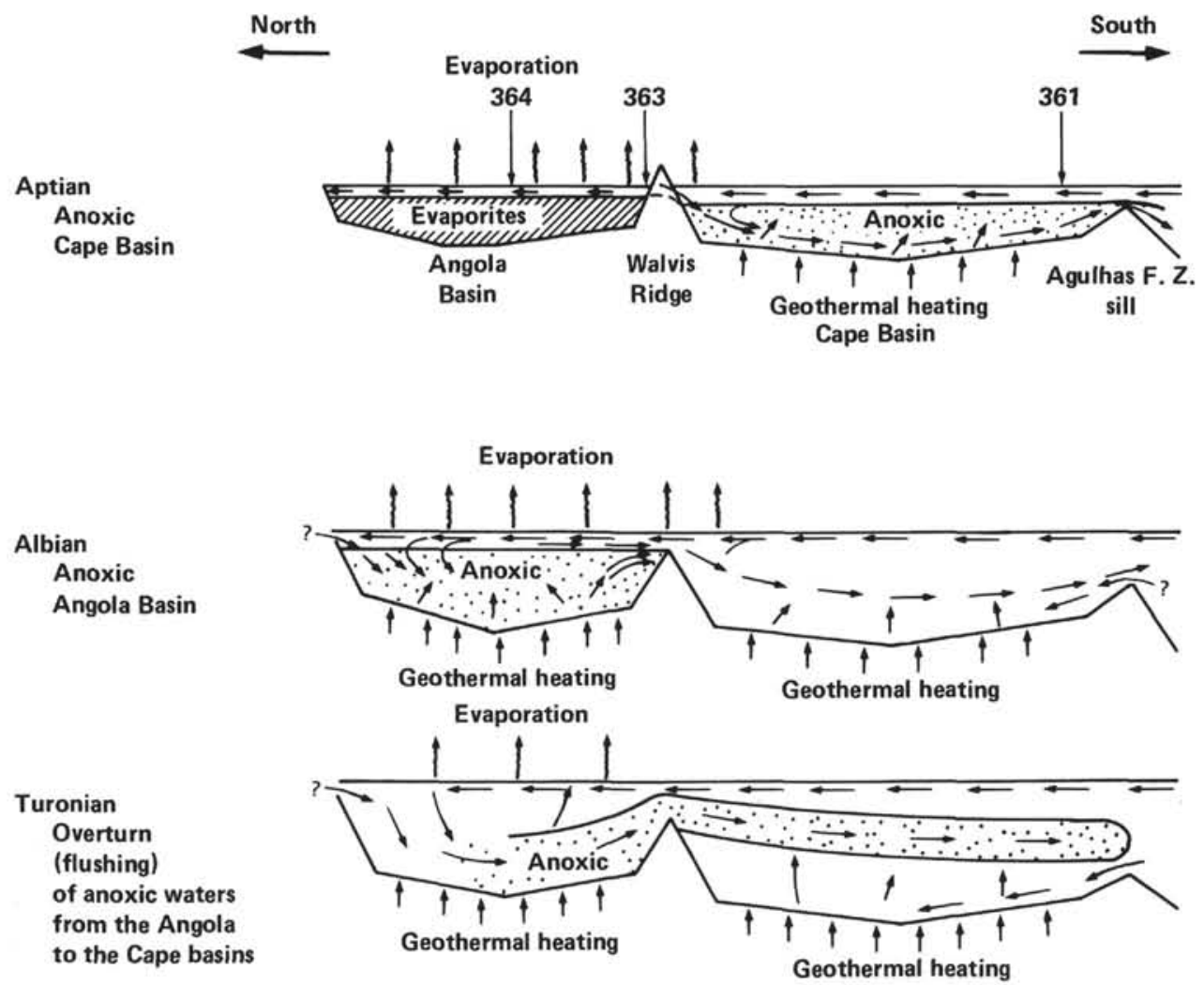

Figure 9. Schematic thermohaline circulation in the South Atlantic during the Cretaceous. Reducing conditions in the South Atlantic can be attributed to salinity stratification and sluggish circulation. This is a schematic diagram by Natland (1978) which summarizes their controls. 